\title{
SURADNJA I UMREŽAVANJE KAO ODREDNICE USPJEŠNOSTI HRVATSKOG DRVNOG KLASTERA
}

Rad prikazuje rezultate anketnog istraživanja provedenog među tvrtkama članicama Hrvatskog drvnog klastera tijekom lipnja, srpnja i kolovoza 2017. godine. Osnovni cilj rada je utvrditi čimbenike koji imaju značajni učinak na percepciju članica o uspješnosti rada Hrvatskog drvnog klastera. Istraživanjem su ispitane percepcije i stavovi tvrtki članica Hrvatskog drvnog klastera vezani uz ostvarenje ciljeva klastera, obilježja klasterskog umrežavanja i suradnje te uz ocjenu učinaka članstva u klasteru na poslovnu uspješnost poduzeća članica. Dodatno, od članica se tražilo da ocijene kvalitetu poslovnog okruženja u Hrvatskoj, ograničenja rada klastera te da ocijene značaj mjera javnih klasterskih politika. U radu su korištene metode deskriptivne statistike, faktorska analiza i metoda višestruke regresije. Rezultati istraživanja ukazuju da su najznačajniji čimbenici koji mogu doprinijeti pozitivnijoj percepciji članica prema uspješnosti rada Hrvatskog drvnog klastera suradnja klastera sa sektorom znanosti i visokog obrazovanja te suradnja unutar klastera. Pritom rezultati ukazuju kako oba identificirana oblika suradnje Hrvatski drvni klaster ne iskorištava u dovoljnoj mjeri.

Ključne riječi: klaster, industrijski klaster, poslovni klaster, suradnja $i$ umrežavanje

* Rašić, dr. sc., viša znanstvena suradnica, Ekonomski institut,Zagreb (e-mail: irasic@eizg.hr). Rad je primljen u uredništvo 19.12.2018. godine, a prihvaćen je za objavu 30.06.2020. godine. Istraživanje je provedeno u okviru projekta SmartEIZ (eng. Strengthening scientific and research capacity of the Institute of Economics Zagreb as a cornerstone for Croatian socioeconomic growth through the implementation of Smart Specialisation) financiranog unutar programa Obzor 2020 kao trogodišnjeg programa jačanja znanstvenih kapaciteta Ekonomskog instituta, Zagreb. 


\section{UVODNA RAZMATRANJA}

Klasteri i klasterska politika sve više zaokupljaju pažnju znanstvenika i nositelja javnih politika. Primjeri uspješnih klastera u industrijskim distriktima razvijenih zemljama, prije svega Italiji i Ujedinjenom Kraljevstvu pružili su poticaj istraživanjima na temu klastera i formuliranja i provedbe klasterske politike (Hendry i Brown, 2006, Bertolini i Giovanetti, 2006). Rezultati provedenih istraživanja ukazuju da klasteri mogu biti ključan pokretač konkurentnosti, inovacija, rasta, zaposlenosti i produktivnosti određenog gospodarskog sektora i prostora na kojem se nalaze (Aletnburg i Meyer-Stamer, 1999; Scmitz i Nadvi, 1999).

S obzirom na način osnivanja klastera u Hrvatskoj se razlikuju dva tipa klastera, klasteri uspostavljeni na načelu odozgo prema dolje (eng. top-down) i klasteri uspostavljeni prema načelu odozdo prema gore (eng. bottom-up). Dok kod prvog tipa klastera inicijativa za uspostavu klastera dolazi od strane države odnosno nositelja javne politike, drugi se tip klastera uspostavlja isključivo na inicijativu interesno povezanih poslovnih subjekata, budućih članica klastera. Uplitanje države poželjno je rješenje u situacijama kada poslovni sektor ne vidi priliku ni potrebu za stvaranjem klastera. Udruživanjem dionika unutar određene djelatnosti potiče se da se postojeće snage iskoriste na najprikladniji način. Nakon što proces povezivanja interesnih skupina u klaster završi i klaster oživi, nositelji javnih politika obično prestaju sa svojim djelovanjem. Primjer prvog tipa klastera u Hrvatskoj su klasteri konkurentnosti ${ }^{1}$, osnovani 2013. godine u obliku neprofitnih organizacija koje okupljaju gospodarstvenike određenog sektora, predstavnike regionalne i lokalne samouprave te predstavnike znanstveno-istraživačkih institucija (tzv. ,triple helix“" model ${ }^{2}$ ). Klastere konkurentnosti osnovala je Vlada Republike Hrvatske na inicijativu Ministarstva gospodarstva, a glavni cilj bio je potaknuti suradnju u strateškom promišljanju, aktivnostima i projektima namijenjenima uključenim dionicima u prepoznatim industrijskim sektorima hrvatskog gospodarstva te povećanje konkurentnosti cjelokupnih sektora. Klasteri konkurentnosti osnovani su kao provedbeni instrument Strategije pametne specijalizacije ${ }^{3}$.

${ }^{1}$ Osnovano je trinaest klastera konkurentnosti koji predstavljaju trinaest sektora: prehrambeno-prerađivački sektor; drvno-prerađivački sektor; automobilski sektor; sektor kreativnih i kulturnih industrija; industrija tekstila, kože i obuće; obrambena industrija; sektor građevinske industrije; sektor elektro-energetskih i proizvodnih strojeva i tehnologija; sektor zdravstvene industrije; industrija kemije, plastike i gume; sektor ICT industrije; sektor pomorske industrije i sektor personalizirane medicine.

${ }^{2}$,Triple helix“ model podrazumijeva uključenost privatnog sektora, znanstveno-istraživačkog sektora i javnog sektora.

3 Vlada Republike Hrvatske je na 12. sjednici održanoj 30. ožujka 2016. donijela Odluku o donošenju Strategije pametne specijalizacije Republike Hrvatske za razdoblje od 2016. do 2020. godine i usvajanju Akcijskog plana za provedbu Strategije pametne specijalizacije Republike Hrvatske za razdoblje od 2016. do 2017. godine. 
Ipak, povijesno gledano, uspostava klastera prema načelu odozgo prema dolje u Hrvatskoj započela je 2003. godine natječajem Ministarstva za obrt, malo i srednje poduzetništvo za dodjelu sredstava za izradu studija o mogućnosti razvoja klastera u pojedinim industrijama (Samaržija, 2014). Na natječaj su se mogla prijaviti gospodarska interesna udruženja i institucije (primjerice poduzetnički i tehnološki centri, istraživački instituti, fakulteti, gospodarske komore i slično). Tim natječajem sufinancirani su sljedeći projekti i institucije u drvnoj industriji: Šumarski fakultet, Zagreb - Projekt za razvoj klastera u preradi drva, proizvodnji namještaja i proizvodnji i preradi papira u RH; Šumarski fakultet, Zagreb - Projekt za razvoj klastera proizvođača proizvoda iz slavonske hrastovine; Centar za promicanje i razvoj drvne industrije, Rijeka - Uspostava drvoprerađivačkog klastera u Lici i Gorskom kotaru; Poduzetnički centar LEDA, Vukovarsko srijemska županija, Strateški savez klaster drvne industrije.

Kada je riječ poslovnim klasterima, prema podacima Hrvatske gospodarske komore, u Hrvatskoj je u 2017. godini bilo aktivno 65 poslovnih klastera koji su okupljali 460 poslovnih subjekata. U ovakvim okolnostima kada inicijativa za udruženje u klaster dolazi od poduzeća, budućih članica klastera, uloga vladinih institucija bila bi pružiti podršku naporima gospodarskih subjekata te omogućiti kvalitetne uvijete kojima bi se snaga gospodarskog sektora mogla nesmetano razvijati i stvoriti odgovarajuću strukturu klastera.

U ovom radu prikazani su rezultati anketnog istraživanja provedenog među tvrtkama članicama Hrvatskog drvnog klastera tijekom lipnja, srpnja i kolovoza 2017. godine. Osnovni cilj rada je identificirati čimbenike koji imaju značajni utjecaj na percepciju poduzeća članica o uspješnosti rada Hrvatskog drvnog klastera. Istraživanjem su ispitane i percepcije i stavovi poduzeća članica Hrvatskog drvnog klastera vezani uz ostvarenje ciljeva klastera, obilježja klasterskog umrežavanja i suradnje te uz ocjenu učinaka članstva u klasteru na poslovnu uspješnost poduzeća članica. Dodatno, od ispitanika se tražilo da ocijene kvalitetu poslovnog okruženja, barijere rada klastera te da ocijene preporuke za nositelje javnih politika usmjerenih na razvoj poslovnih klastera.

Osnovne hipoteze rada su:

H1 - Uspostava i jačanje suradnje poslovnog klastera sa znanstveno-istraživačkim i visokoobrazovnim institucijama ima značajan pozitivan utjecaj na percepciju članica o uspješnosti rada klastera u cjelini.

H2 - Umrežavanje i jačanje suradnje unutar poslovnog klastera ima značajan pozitivan utjecaj na percepciju članica o uspješnosti rada klastera u cjelini.

Hrvatski drvni klaster (HDK) odabran je kao primjer uspješnog poslovnog klastera u Hrvatskoj s dužom tradicijom postojanja. Prema mišljenju velikog broja 
stručnjaka i znanstvenika riječ je o jednom od najznačajnijih poslovnih klastera ne samo u sektoru drvne industrije i industrije namještaja, već u cjelokupnom hrvatskom gospodarstvu (Dragičević i Obadić, 2013; Kersan Škabić, 1998; Kavran, 2013). Hrvatski drvni klaster osnovan je 2002. godine kao Centar za promociju i razvoj drvne industrije, 2010. godine je preregistriran u Drvni centar d.o.o., da bi od 2013. godine djelovao kao profesionalna udruga s dvoje zaposlenih (Samaržija, 2014). Hrvatski drvni klaster okuplja poslovne subjekte registrirane u djelatnostima prerade drva (odjeljak C16) i proizvodnje namještaja (odjeljak C31) ${ }^{4}$. HDK je u 2017. godini okupljao 60 poslovnih subjekta s ukupno 5.300 zaposlenih, što je činilo 22,3 posto zaposlenosti sektora prerade drva i proizvodnje namještaja ${ }^{5}$. Klaster je osnovan s ciljem unaprjeđenja održive konkurentnosti sektora prerade drva i proizvodnje namještaja, osobito vezano uz poticanje i promociju unutarsektorske i međusektorske suradnje.

\section{POJMOVNO ODREĐENJE KLASTERA}

Pojam klaster je engleskog podrijetla (eng. cluster) i znači grozd, gomila, grupa, mnoštvo (Školska knjiga, 2017). Termin se koristi u različitim disciplinama poput kemije, biologije, medicine, računarstva, glazbe itd. U ekonomsku literaturu pojam klastera uvodi Michael Porter u svom djelu „Konkurentske prednosti nacija“" (eng. Competitive Advantage of Nations) iz 1990. godine (Porter, 1990). Porter (1990) klastere definira kao geografske koncentracije međusobno povezanih poduzeća i drugih institucija, koji nude kritičnu masu znanja, tehnologija, resursa i sredstava bitnih za jačanje konkurentnosti članica klastera i klastera kao cjeline (Porter, 1990.). Prema Porteru klasteri mogu biti prisutni u srodnim ili različitim djelatnostima, okupljati subjekte iz različitih područja koji utječu na stjecanje konkurentske prednosti, primjerice dobavljače, potporne institucije (banke, znanstveno-obrazovne, istraživačke centre) ili subjekte koji omogućuju pristup specijaliziranoj infrastrukturi. Kako se subjekti unutar klastera mogu nalaziti u istim ili različitim fazama proizvodnog procesa, uobičajeno je da dijele znanje, tehnologiju, inpute, infrastrukturu i radnu snagu. Članove klastera stoga povezuju zajednički interesi na području nabave, kupaca, specijaliziranih usluga, radne snage, ali i drugih resursa te povezuju ih zajedničke potrebe i komplementarnost (Porter, 2000).

\footnotetext{
${ }^{4}$ Djelatnosti kategorizirane prema Nacionalnoj klasifikaciji djelatnosti NKD 2007.

5 Podaci preuzeti od Hrvatskog drvnog klastera.
} 
Premda se pojmovno određenje klastera veže uz Portera, teorijski korijeni dolaze iz Marshallove teorije aglomeracija (Marshall, 1920). Za razliku od Portera koji klastere identificira kao geografske koncentracije povezanih poduzeća i institucija, Marshall klastere naziva industrijskim distriktima (Lorenzen, 2003). Industrijski distrikti vezani su za geografske regije, a njihove su članice međusobno povezane protokom roba i usluga. Industrijski klaster razlikuje se od industrijskog distrikta po tome što se klaster jedne industrijske grane odlikuje čitavim lancima funkcionalno povezanih djelatnosti, pri čemu svaka djelatnost znači dodatnu vrijednost i to počevši od dobavljača do konačnog proizvoda i njegovog plasmana na tržište. U ove lance uključeni su brojni pružatelji usluga, a to mogu, primjerice, biti i financijske institucije. Povezanost članica klastera utemeljena je na zajedničkom interesu i jača je u odnosu na povezanost između subjekata industrijskog distrikta. Marshall je još početkom prošlog stoljeća zaključio da industrijsko klasteriranje dovodi do pozitivnih aglomeracijskih ekonomija na određenoj lokaciji, i to zahvaljujući korištenju lokalnih informacija i prelijevanja znanja, lokalne ponude nerazmijenjenih inputa i kvalificirane lokalne radne snage. Upravo aglomeracijske eksternalije (oblik eksternalija koje nastaju uslijed industrijske specijalizacije) Marshall smatra glavnim pokretačem klasterskog umrežavanja poduzeća. Aglomeracijske eksternalije rezultat su djelovanja netržišnih sila koje dovode do rastućih prinosa poduzeća. Proučavajući industrijske distrikte u Sheffieldu i Bedrordshireu u Ujedinjenom Kraljevstvu, Marshall je uočio visoku razinu lokaliziranog znanja sa snažnim vezama između lokalnih poduzeća. Opazio je proces dijeljenja znanja između sudionika industrijskih distrikta koji rezultira diseminacijom izuma i unaprjeđenja. Lokalizacija poduzetnicima pruža priliku za specijalizaciju i stjecanje određenih koristi koje proizlaze iz fizičke blizine s poduzećima iz iste industrije.

Nadalje, značajan doprinos i proširenje Marshallovoj teoriji lokalizacije dali su i Kenneth-Arrow (1962) i Romer (1986). Marshall, Arrow i Romer navode da do prelijevanja znanja može doći između kompanija istog sektora i da je ono potaknuto lokalnim koncentracijama određene industrije (Marshall-ArrowRomer (MAR) tip lokalizacije ili eksternalije ,specijalizacije“) (Marshall, 1890, Arrow, 1962, Romer, 1986). Prema MAR tipu eksternalija, prelijevanje znanja u specijaliziranim i geografski koncentriranim industrijama stimulira rast. Fizička blizina poduzeća iz istog sektora doprinosi većem stupnju specijalizacije što za posljedicu ima veću produktivnost. Koncentracija, istovremeno, smanjuje rizike poduzeća vezane uz pronalaženje kvalificirane radne snage zbog postojanja značajnog lokalnog tržišta rada s adekvatnim kvalifikacijama, ali i rizike radnika koji imaju veću slobodu izbora poslodavca s obzirom na svoje kvalifikacije. Dodatno, koncentracija poduzeća iz istog sektora pospješuje interakciju ljudi čime se potiču razmjene ideja i informacija kao i nove poduzetničke aktivnosti. 
Pored spomenutih definicija, literatura navodi i brojne druge koncepte i definicije klastera. Industrijski klaster definira se tako i kao aglomeracija poduzeća specifičnog profila specijalizacije na prostorno razgraničenom području (Altenburg i Meyer Stamer, 1999). Prema Simmie i Sennett (1999) klaster čini veći broj međusobno povezanih poduzeća koji posluju pod jednakim tržišnim uvjetima i intenzivno surađuju, uglavnom putem opskrbnih lanaca. Predstavnici tzv. talijanske škole zalažu se za širu definiciju klastera odnosno smatraju da na uspjeh industrijskog distrikta pored ekonomskih utječu i teritorijalni, društveno-kulturni i povijesni faktori (Morosini, 2004). Morosini industrijski klaster određuje kao društveno-gospodarski entitet kojeg sačinjava društvena zajednica ljudi i gospodarskih subjekata smještenih u neposrednoj blizini. Tallman, Jenkins i Henry (2004) naglašavaju interakciju članova klastera i definiraju klaster ne samo kao aglomeraciju poduzeća smještenih u geografskoj blizini, već i kao grupu koju obilježava učestalo dijeljenje i prelijevanje znanja. Prema definiciji OECD-a klaster čini mreža snažno povezanih poduzeća, proizvođača znanja poput sveučilišta, istraživačkih instituta i I\&R kompanija, institucija koje su mostovi poput konzultanata i posrednika te klijenata. Svi su oni međusobno povezani u lancu proizvodnje dodane vrijednosti i to putem input-output odnosa, zajedničkih normi, konvencija, društvenog kapitala, ljudskih resursa itd. (OECD, 1998).

Klastere obilježava dvojnost u smislu da predstavljaju funkcionalno definirane sustave povezanih aktivnosti i prostorno definirane sustave sličnih i povezanih aktivnosti. Jedna od mogućih kategorizacija klastera stoga se temelji na razlici između funkcionalno povezanih sustava, poznatih kao industrijski klasteri, i prostornih grupacija sličnih i povezanih poduzeća i industrija, poznatih kao regionalni ili lokalni klasteri (Dragičević i Obadić, 2013). Industrijski klaster najčešće je sastavljen od poduzeća i drugih sudionika koji zajedno razvijaju, proizvode, trguju različitim tipovima dobara i usluga, razmjenjuju informacije i znanje. On ne mora biti prostorno ograničen samo na jedno geografsko područje, već može obuhvatiti širi opseg, pokrivajući na taj način čitave države. Regionalni klaster predstavlja prostornu koncentraciju poduzeća i drugih subjekata koji obavljaju iste ili slične djelatnosti, stvarajući osnovu koja efikasno potiče učinke širenja znanja i stvaranje različitih oblika učenja i prilagođavanja. Ove klastere, uglavnom, čine manja i srednja poduzeća, a oni predstavljaju važan instrument za promoviranje regionalne konkurentnosti i rast novog zapošljavanja.

Svim navedenim definicijama zajedničko je da je klaster grupa poduzeća u vertikalnim i horizontalnim odnosima koja su aktivna u istoj djelatnosti te istovremeno međusobno i konkuriraju i surađuju. Grupa poduzeća usko je povezana s drugim institucijama i istraživačkim centrima i vladinim agencijama te dijeli znanja putem prelijevanja. 
I. RAŠIĆ: Suradnja i umrežavanje kao odrednice uspješnosti Hrvatskog drvnog klastera EKONOMSKI PREGLED, 72 (1) 113-154 (2021)

\section{PREGLED LITERATURE}

Empirijska istraživanja na temu industrijskih klastera većim su dijelom usmjerena na ispitivanje učinaka klastera na poslovnu i inovacijsku aktivnost poduzeća članica. Rezultati provedenih istraživanja ukazuju na pozitivne učinke industrijskih klastera na poslovnu uspješnost poduzeća članica. Primjerice Altenburg i Meyer-Stamer (1999) utvrdili su da klastersko udruživanje pospješuje rast i razvoj malih i srednjih poduzeća (Altenburg i Meyer-Stamer, 1999). Istraživanja klastera u Italiji i Španjolskoj, pokazuju da snažna povezanost industrija i potpornih institucija ima signifikantan pozitivan učinak na produktivnost i financijsku uspješnost poduzeća članica klastera (Hervas-Oliver i Albors - Garrigos, 1997). Također, Hendry i Brown su pokazali kako postoji pozitivna veza između lokalnih mreža i financijske uspješnosti poduzeća unutar klastera u Ujedinjenom Kraljevstvu (Hendry i Brown, 2006). Slično, na temelju istraživanja provedenog na tvrtkama članicama klastera u Tajvanu, utvrđeno je kako je lokalna mreža pozitivno povezana s inovacijama proizvoda i procesa, kao i financijskom izvedbom klasteriranih tvrtki (Chiu, 2009). S druge strane, Bertolini i Giovanetti utvrdili su da je umrežavanje lokalnih poduzeća najvećim dijelom potaknuto time što su poduzeća iz povezanih djelatnosti smještena na istom geografskom području odnosno fizički blizu jedna drugima (Bertolini i Giovanetti, 2006). Umrežavanje omogućuje klasteriranim talijanskim poduzećima da poboljšaju svoju inovacijsku izvedbu. Slično, rezultati istraživanja ukazuju na pozitivnu vezu između inovacijske aktivnost klasteriranih poduzeća i prelijevanja znanja unutar industrijskog klastera (Kesidou i Szirmai, 2008) te prisutnost povezanih industrija u klasteru (Muscio, 2006). Schmitz i Nadvi (1999) ističu kako aglomeracije poduzeća iz iste ili sličnih djelatnosti dovode do niza prednosti kao što su ponuda specijaliziranih radnika, jednostavniji i brži pristup dobavljačima specijaliziranih inputa i usluga i brza diseminacija znanja. Te prednosti, poznate pod nazivom lokalizirane eksterne ekonomije, mogu doprinijeti smanjenju troškova poduzeća u klasteru.

Praćenje uspješnosti rada industrijskih klastera važno je kako za upravljačka tijela samog klastera i njegove članice, tako i za nositelje klasterskih politika. U cilju formuliranja mjera klasterskih politika te ocjena učinaka provedenih mjera, nositeljima politika važne su informacije o rezultatima rada klastera. Dodatno, identifikacija slabosti klastera važna je kako bi se uspostavile nove mjere za poboljšanje politika razvoja klastera (DTI, 2005). Literatura koja obrađuje temu evaluacije klastera (Turok, 1990; Diez, 2001, Davis, Arturs, Cassidy i Wolfe., 2006) fokus stavlja na evaluaciju klasterskih politika, definirajući pritom evaluaciju fazom životnog ciklusa politike, dok se ostali fokusiraju na evaluaciju uspješnosti izvedbe klaster inicijative i samog programa (Sölvell, 2009).

Fitzgerald, Johnston, Brignall, Silvestro, i Voss (1991.) razlikuju dvije vrste mjera uspjeha neke organizacije. One, koje se odnose na rezultate i one koje se 
odnose na odrednice rezultata. Osim mjera koje se odnose na ekonomske rezultate ili druge mjere koje se mogu mjeriti kvantitativnim pokazateljima, uspjeh klastera također ovisi o kvalitativnim pokazateljima kao što su razina suradnje i društveni kapital.

Istraživanja na temu rezultata i učinaka rada poslovnih klastera u Hrvatskoj prilično su oskudna. Problematika klastera razmatra se u knjizi „Lokalni sustavi malih gospodarskih subjekata“" (Pašalić i Mrnjavac, 2000). Horvat i Kovačević (2004) u djelu „Clusteri put do konkurentnosti“ model klastera ističu kao sredstvo za jačanje konkurentnosti poduzetnika i same regije, uspoređuju teoriju i praksu razvijanja „,clustera“ u razvijenim tržišnim gospodarstvima i u Republici Hrvatskoj, ukazujući na nužnost razvijanja klastera u hrvatskim gospodarskim uvjetima. Nadalje, Dragičević i Obadić u djelu „Klasteri i politike razvoja klastera“ (Dragičević i Obadić, 2013) daju sveobuhvatan pregled različitih teorijskih spoznaja o klasterima, konceptima, tipovima i njihovim oblicima te metodama analize, ukazujući na značaj klastera za rast konkurentnosti u uvjetima globalne ekonomije. Autorice zaključuju kako je utjecaj klastera na promoviranje regionalne i industrijske konkurentnosti prvenstveno determiniran međusobnom suradnjom nezavisnih članica što dovodi do različitih inovacijskih procesa koji posljedično utječu na konkurentnost.

\section{METODOLOGIJA ISTRAŽIVANJA}

Podaci korišteni u istraživanju prikupljeni su anketnim ispitivanjem predstavnika članica Hrvatskog drvnog klastera. Populacija je obuhvaćala 61 aktivnu članicu HDK-a. Anketno ispitivanje provedeno je tijekom srpnja i kolovoza 2017. godine web anketom podržanom od strane računala (eng. Computer-Assisted Web Interviewing Method - CAWI) na uzorku od 34 poduzeća, što predstavlja stopu povrata od 55,7 posto. Ispitanici su birani metodom slučajnog odabira. Dizajnu upitnika prethodio je pregled literature, jedan intervju s predstavnikom Hrvatskog drvnog klastera te 4 intervjua provedena s predstavnicima članica klastera.

Cilj anketnog istraživanja bio je ispitati i analizirati stavove i percepcije članica HDK-a vezane uz uspješnost rada klastera, jačinu i kvalitetu međusobne suradnje članica klastera kao i suradnje između članica klastera i vanjskih dionika. Dodatno, istraživanjem je ispitano kako članice klastera percipiraju ključne barijere na koje klaster nailazi u svom radu, poslovno i gospodarsko okruženje u Hrvatskoj, kao i relevantnost mjera javnih klasterskih politika.

Instrument za prikupljanje empirijskih podataka bio je strukturirani upitnik s pitanjima zatvorenog tipa u obliku nominalnih i ordinalnih ljestvica (Likertova ljestica 1-5). Upitnik je podijeljen na dva dijela. U analizu su uključeni odgovori na pi- 
tanja svrstani u šest tematskih cjelina. Prva cjelina obuhvaća obilježja poduzeća članica iz koje dolaze ispitanici, druga uključuje vrednovanje dimenzija suradnje unutar klastera i klastera s vanjskim dionicima. Treća grupa pitanja odnosi se na prosudbe ispitanika o učincima klasterskog umrežavanja i klasterskih resursa na način poslovanja i poslovnu uspješnost članica. Četvrta cjelina uključuje vrednovanje ključnih barijera radu klastera. Peta cjelina se odnosi na vrednovanje mjera javnih klasterskih politika, a šesta na ocjenu poslovnog i gospodarskog okruženja u Hrvatskoj.

Obrada podataka obavljena je u statističkom programu SPSS. Statističkoj analizi prethodio je izračun Cronbachov alfa koeficijenta pouzdanosti za navedene tematske cjeline pitanja (tablica 1). S obzirom da alfa koeficijenti za svih 11 ljestvica poprimaju vrijednosti veće od 0,80 , može se zaključiti da ljestvice imaju izvrsnu razinu pouzdanosti, odnosno potvrđuju se kao valjani instrumenti za mjerenje stavova i mišljenja ispitanika (Cronbach, 1951).

\section{Tablica 1 .}

\section{KOEFICIJENTI UNUTARNJE KONZISTENCIJE (CRONBACH ALFA) ZA 11 LJESTVICA UPITNIKA}

\begin{tabular}{|l|c|c|}
\hline \multicolumn{1}{|c|}{ Ljestvice } & $\boldsymbol{\alpha}$ - koeficijent & Broj tvrdnji \\
\hline $\begin{array}{l}\text { Ocjena važnosti aktivnosti koje provodi Hrvatski drvni } \\
\text { klaster }\end{array}$ & 0,924 & 9 \\
\hline $\begin{array}{l}\text { Ocjene značaja aktivnosti klastera prema tome treba li } \\
\text { ih HDK koordinirati }\end{array}$ & 0,929 & 16 \\
\hline Obilježja suradnje i umrežavanja putem HDK-a & 0,832 & 7 \\
\hline Snaga suradnje i umrežavanja putem HDK-a & 0,945 & 9 \\
\hline $\begin{array}{l}\text { Ocjena značaja resursa unutar HDK-a kao izvora } \\
\text { konkurentske prednosti za vaše poduzeće }\end{array}$ & 0,961 & 14 \\
\hline Ocjena poslovnog i ekonomskog okruženja u Hrvatskoj & 0,956 & 8 \\
\hline $\begin{array}{l}\text { Ocjena učinaka HDK-a na poslovnu uspješnost } \\
\text { poduzeća članova klastera }\end{array}$ & 0,922 & 17 \\
\hline $\begin{array}{l}\text { Ocjena učinaka HDK-a na aspekte poslovanja poduzeća } \\
\text { članova klastera }\end{array}$ & 0,972 & 14 \\
\hline Ocjena glavnih ograničenja za rad HDK-a & 0,845 & 7 \\
\hline $\begin{array}{l}\text { Ocjena preporuka danih javnih politika usmjerenih na } \\
\text { poboljšanje rezultata poslovnih klastera }\end{array}$ & 0,961 & 11 \\
\hline $\begin{array}{l}\text { Ocjena relevantnosti vladinih politika i mjera za razvoj } \\
\text { poslovnih klastera u Hrvatskoj }\end{array}$ & 0,967 & 17 \\
\hline
\end{tabular}

Izvor: izračun autorice 


\subsection{Analiza uzorka}

U istraživanju je sudjelovalo 34 poduzeća odnosno 34 ispitanika koji su upitnik ispunjavali samostalno. Gledano prema funkciji koju obnašaju u poduzeću, najveći dio ispitanika čine glavni direktori (39,4 posto), iza kojih slijede viši menadžeri poput voditelja poslovnih jedinica (27 posto), 18 posto ispitanika obnaša funkciju predsjednika ili članova nadzornog odbora ili uprave, a glavni izvršni direktori čine tek 6,1 posto ispitanika (tablica 2). Čak jedna trećina anketiranih poduzeća dolazi iz Primorsko-goranske županije, što je i očekivano s obzirom na to da se radi o području Hrvatske sa snažnom resursnom osnovicom za razvoj drvne industrije. Zatim slijede poduzeća iz Zagrebačke, Sisačko-moslavačke, Varaždinske i Međimurske županije. Detaljna distribucija ispitanika prema županijama prikazana je u tablici 3 .

\section{Tablica 2 .}

\section{STRUKTURA ISPITANIKA PREMA POLOŽAJU U ZAPOSLENJU I PREMA ŽUPANIJI SJEDIŠTA PODUZEĆA}

\begin{tabular}{|l|c|}
\hline \multicolumn{1}{|c|}{ Položaju u zaposlenju } & $\mathbf{n = 3 4}$ \\
\hline Direktor & $39,4 \%$ \\
\hline Viši menadžer & $30,3 \%$ \\
\hline Član uprave & $6,1 \%$ \\
\hline Predsjednik uprave & $6,1 \%$ \\
\hline Predsjednik nadzornog odbora & $6,1 \%$ \\
\hline Izvršni direktor & $6,1 \%$ \\
\hline Komercijalista & $6,1 \%$ \\
\hline Administrator & $6,1 \%$ \\
\hline
\end{tabular}

Izvor: izračun autorice 
I. RAŠIĆ: Suradnja i umrežavanje kao odrednice uspješnosti Hrvatskog drvnog klastera EKONOMSKI PREGLED, 72 (1) 113-154 (2021)

Tablica 3.

STRUKTURA ISPITANIKA PREMA ŽUPANIJI SJEDIŠTA PODUZEĆA

\begin{tabular}{|l|c|}
\hline \multicolumn{1}{|c|}{ Položaju u zaposlenju } & $\mathbf{n = 3 4}$ \\
\hline Primorsko-goranska & $31,4 \%$ \\
\hline Zagrebačka & $14,3 \%$ \\
\hline Sisačko-moslavačka & $11,4 \%$ \\
\hline Varaždinska & $8,6 \%$ \\
\hline Međimurska & $5,7 \%$ \\
\hline Virovitičko-podravska & $5,7 \%$ \\
\hline Grad Zagreb & $5,7 \%$ \\
\hline Vukovarsko-srijemska & $2,9 \%$ \\
\hline Karlovačka & $2,9 \%$ \\
\hline Istarska & $2,9 \%$ \\
\hline
\end{tabular}

Izvor: izračun autorice

Kao što je vidljivo iz tablice 4, u uzorku su najviše zastupljeni ispitanici iz poduzeća od 10 do 50 zaposlenih (44,1 posto) koja posluju barem 20 godina (65,7 posto) s prosječnim ukupnim godišnjim prihodima od 2 do 10 milijuna eura (43,8 posto). 50 posto ispitanih poduzeća čine izvozno orijentirana poduzeća koja više od 70 posto svojih prihoda ostvaruju putem izvoza (50 posto poduzeća). Većina anketiranih poduzeća inpute za proizvodnju nabavlja na domaćem tržištu (51,5 posto), dok proizvode prodaje na međunarodnom tržištu (70,6 posto). 
Tablica 4 .

STRUKTURA UZORKA PREMA OBILJEŽJIMA PODUZEĆA, N = 34

\begin{tabular}{|c|c|c|c|c|c|c|c|}
\hline \multicolumn{8}{|c|}{ Starost poduzeća (u godinama) } \\
\hline & $<10$ & 10 do 20 & \multicolumn{2}{|c|}{20 do 30} & Iznad 30 & \multicolumn{2}{|c|}{ Ukupno } \\
\hline Učestalost & 6 & 5 & \multicolumn{2}{|c|}{18} & 5 & \multicolumn{2}{|c|}{34} \\
\hline Postotak & $17,1 \%$ & $14,7 \%$ & \multicolumn{2}{|c|}{$51,4 \%$} & $14,3 \%$ & \multicolumn{2}{|c|}{$100 \%$} \\
\hline \multicolumn{8}{|c|}{ Broj zaposlenih (godišnji prosjek 2014. - 2016.) } \\
\hline & $<10$ & 10 do 50 & \multicolumn{2}{|c|}{50 do 250} & Više od 250 & \multicolumn{2}{|c|}{ Ukupno } \\
\hline Učestalost & 4 & 15 & \multicolumn{2}{|c|}{13} & 2 & \multicolumn{2}{|c|}{34} \\
\hline Postotak & $11,8 \%$ & $44,1 \%$ & \multicolumn{2}{|c|}{$38,2 \%$} & $5,9 \%$ & \multicolumn{2}{|c|}{$100 \%$} \\
\hline \multicolumn{8}{|c|}{ Kategorija prema visini ostvarenih prihoda (godišnji prosjek 2014. - 2016.) } \\
\hline & $\begin{array}{c}<2 \mathrm{mil} \\
\quad \text { eura }\end{array}$ & \multicolumn{2}{|c|}{$2-10$ mil. eura } & \multicolumn{2}{|c|}{$10-50$ mil. eura } & \multicolumn{2}{|c|}{ Ukupno } \\
\hline Učestalost & 11 & \multicolumn{2}{|c|}{14} & \multicolumn{2}{|r|}{7} & \multicolumn{2}{|c|}{32} \\
\hline Postotak & $34,4 \%$ & & & & $21,9 \%$ & & $0 \%$ \\
\hline & & Z (godis & prosjek & 2014 & - 2016.) & & \\
\hline & do $10 \%$ & $\begin{array}{r}10 \% \mathrm{~d} \\
30 \%\end{array}$ & $\begin{array}{r}30 \% \\
50\end{array}$ & & $\begin{array}{c}50 \% \text { do } \\
70 \%\end{array}$ & $\begin{array}{l}70 \% \text { i } \\
\text { više }\end{array}$ & Ukupno \\
\hline Učestalost & 4 & 2 & 7 & & 3 & 16 & 32 \\
\hline Postotak & $12,5 \%$ & $6,3 \%$ & 21,9 & & $9,4 \%$ & $50 \%$ & $100 \%$ \\
\hline & & Trži & nabave & input & & & \\
\hline & $\begin{array}{r}\text { Loka } \\
\text { regionaln }\end{array}$ & \begin{tabular}{l|} 
ta/ \\
tržišta
\end{tabular} & $\begin{array}{r}\text { Nacio } \\
\text { trž }\end{array}$ & te & $\begin{array}{r}\text { Među } \\
\text { tri }\end{array}$ & $\begin{array}{l}\text { harodno } \\
\text { išste }\end{array}$ & Ukupno \\
\hline Učestalost & 9 & & 1 & & & 7 & 33 \\
\hline Postotak & 27,3 & & 51 , & & & $2 \%$ & $100 \%$ \\
\hline & & & ajno tr & ište & & & \\
\hline & $\begin{array}{r}\text { Loka } \\
\text { regionaln }\end{array}$ & $\begin{array}{l}\text { a/ } \\
\text { tržišta }\end{array}$ & $\begin{array}{r}\text { Nacio } \\
\text { trži }\end{array}$ & alno & $\begin{array}{r}\text { Među } \\
\text { tri }\end{array}$ & $\begin{array}{l}\text { narodno } \\
\text { ište }\end{array}$ & Ukupno \\
\hline Učestalost & 2 & & 8 & & & 24 & 34 \\
\hline Postotak & 5,9 & & 23 , & & & $6 \%$ & $100 \%$ \\
\hline
\end{tabular}

Izvor: izračun autorice na temelju podataka iz Poslovne Hrvatske i ankete 
I. RAŠIĆ: Suradnja i umrežavanje kao odrednice uspješnosti Hrvatskog drvnog klastera EKONOMSKI PREGLED, 72 (1) 113-154 (2021)

\section{Rezultati}

\subsection{Rezultati anketnog ispitivanja-deskriptivna analiza}

U tablici 5 prikazan je prosječan rang ciljeva Hrvatskog drvnog klastera s obzirom na važnost koju su svakom cilju dodijelile članice klastera obuhvaćene uzorkom (tablica 5). Tvrdnje koje se odnose na ciljeve formulirane su na temelju razgovora s upravom Hrvatskog drvnog klastera i pregledom internih akata $\mathrm{Hr}$ vatskog drvnog klastera. Među ispitanim članicama HDK-a prevladava mišljenje da je najvažniji cilj djelovanja HDK-a rast konkurentnosti članica i cjelokupnog sektora. Zatim slijede ciljevi poput osiguranja zajedničkog pristupa inputima i više kvalitete inputa, razvoj i komercijalizacija inovacija, unaprjeđivanja kvalitete finalnih proizvoda te poticanja transfera znanja.

\section{Tablica 5 .}

\section{RANG CILJEVA HRVATSKOG DRVNOG KLASTERA (PROSJEČNI RANG), N = 34}

\begin{tabular}{|l|c|}
\hline Rast konkurentnosti članica klastera i cjelokupnog sektora & 1. \\
\hline Zajednički pristup inputima i viša kvaliteta inputa & 2. \\
\hline Razvoj i komercijalizacija inovacija & 3. \\
\hline Unapređivanje kvalitete finalnih proizvoda & 4. \\
\hline Poticanje transfera znanja među poslovnim subjektima unutar i izvan klastera & 5. \\
\hline $\begin{array}{l}\text { Unaprjeđivanje kvalitete ljudskog kapitala, izgradnja kompetencija i stalno } \\
\text { usavršavanje }\end{array}$ & \\
\hline Ulaganje u razvoj dizajna, promociju i izgradnju brendova domaće industrije & \\
\hline Brži razvoj malih i srednjih poduzeća u klasteru & \\
\hline Zajednički nastup na prodajnim tržištima & \\
\hline
\end{tabular}

Izvor: obrada autorice

Najznačajnije aktivnosti Hrvatskog drvnog klastera su, prema mišljenju najvećeg dijela ispitanika, suradnja s dobavljačima inputa (prosječna ocjena 4, modalna ocjena 4 i 5), zatim aktivnost umrežavanja i promidžbe klastera (prosječna ocjena 3,94, modalna ocjena 5), sektorsko lobiranje u Vladi RH (prosječna ocjena 3,94, modalna ocjena 4) te aktivnosti vezane uz pripremu prijava za EU projekte (prosječna ocjena 3,76, modalna ocjena 5) (tablica 6). 
Tablica 6.

OCJENA AKTIVNOSTI HDK-a PREMA ZNAČAJU, N = 34.

\begin{tabular}{|c|c|c|c|}
\hline & $\begin{array}{c}\text { Potpuno } \\
\text { nevažno/ } \\
\text { nevažno }\end{array}$ & $\begin{array}{c}\text { Niti } \\
\text { nevažno } \\
\text { niti važno }\end{array}$ & $\begin{array}{c}\text { Važno/ } \\
\text { potpuno } \\
\text { važno }\end{array}$ \\
\hline $\begin{array}{l}\text { Suradnja sektora s dobavljačima inputa }(\bar{x}=4,09 ; \\
\text { Mo = 4, 5; S.D. = 0,900; min. }=1 ; \text { maks. }=5)\end{array}$ & $11,4 \%$ & $18,6 \%$ & $70,0 \%$ \\
\hline $\begin{array}{l}\text { Umrežavanje i promidžba klastera } \\
\text { (npr. konferencije, sajmovi i sl.) }(\bar{x}=3,94 ; \text { Mo }=5 \text {; } \\
\text { S.D. }=1,153 \text {; min. }=1 \text {; maks. }=5 \text { ) }\end{array}$ & $8,6 \%$ & $22,9 \%$ & $68,6 \%$ \\
\hline $\begin{array}{l}\text { Sektorsko lobiranje u Vladi RH }(\bar{x}=3,94 ; \mathrm{Mo}=4 ; \\
\text { S.D. }=0,983 ; \text { min. }=2 ; \text { maks. }=5)\end{array}$ & $11,4 \%$ & $14,3 \%$ & $74,3 \%$ \\
\hline $\begin{array}{l}\text { Priprema prijava za EU projekte }(\bar{x}=3,94 ; \mathrm{Mo}=5 ; \\
\text { S.D. }=1,206 ; \text { min. }=1 ; \text { maks. }=5)\end{array}$ & $14,3 \%$ & $22,9 \%$ & $62,9 \%$ \\
\hline $\begin{array}{l}\text { Suradnja i razmjena iskustava s domaćim i } \\
\text { međunarodnim partnerskim klasterima }(\bar{x}=3,76 ; \\
\text { Mo }=3 \text { S.D. }=1,062 ; \text { min. }=1 ; \text { maks. }=5)\end{array}$ & $8,8 \%$ & $32,4 \%$ & $58,8 \%$ \\
\hline $\begin{array}{l}\text { Članstvo i djelovanje u nacionalnom klasteru } \\
\text { konkurentnosti } \bar{x}=3,71 ; \text { Mo }=4 ; \text { S.D. }=0,916 \text {; } \\
\text { min. }=1 ; \text { maks. }=5 \text { ) }\end{array}$ & $6,1 \%$ & $30,3 \%$ & $63,6 \%$ \\
\hline $\begin{array}{l}\text { Predlaganje zakonskih i podzakonskih akata } \\
(\bar{x}=3,71 ; \mathrm{Mo}=3 / 5 ; \text { S.D. }=1,168 ; \text { min. }=1 \\
\text { maks. }=5)\end{array}$ & $11,4 \%$ & $31,4 \%$ & $57,1 \%$ \\
\hline $\begin{array}{l}\text { Razvoj struke i sektora/industrije kroz razvijanje } \\
\text { baze sektorskih podataka, izdavanje vlastitih } \\
\text { strukovnih časopisa, prikupljanje i obrada } \\
\text { statističkih podataka, istraživanje i analiza } \\
\text { sektorskih kretanja }(\bar{x}=3,70 ; \text { Mo }=4 ; \text { S.D. }= \\
0,984 ; \text { min. }=1 ; \text { maks. }=5)\end{array}$ & $11,8 \%$ & $23,5 \%$ & $64,7 \%$ \\
\hline $\begin{array}{l}\text { Edukacija upravljačke strukture klastera i članova } \\
(\bar{x}=3,53 ; \text { Mo }=4 ; \text { S.D. }=1,080 \text { min. }=1 \\
\text { maks. }=5)\end{array}$ & $17,1 \%$ & $22,9 \%$ & $60,0 \%$ \\
\hline
\end{tabular}

Izvor: izračun autorice 
Među ispitanicima prevladava stav da su najznačajnije aktivnosti koje bi klaster trebao koordinirati aktivnosti vezane uz informiranje o izvoznim tržištima (prosječna ocjena 4,27, modalna ocjena 5), zajednički marketing i nastup na stranim tržištima (prosječna ocjena 4,15, modalna ocjena 5), zajedničko brendiranje (prosječna ocjena 3,85, modalna ocjena 5), poticanje zajedničkog izvoza iz klastera (prosječna ocjena 3,84, modalna ocjena 4) te aktivnosti zajedničke ponude proizvoda na tržištu (prosječna ocjena 3,79, modalna ocjena 4) (tablica 7).

\section{Tablica 7.}

\section{AKTIVNOSTI KOJE BI HDK TREBAO KOORDINIRATI, N = 34}

\begin{tabular}{|l|c|c|c|c|c|}
\hline & $\begin{array}{c}\text { Aritmetička } \\
\text { sredina }\end{array}$ & Mod & S.D. & $\begin{array}{c}\text { Mini- } \\
\text { mum }\end{array}$ & $\begin{array}{c}\text { Maksi- } \\
\text { mum }\end{array}$ \\
\hline Informiranje o izvoznim tržištima & 4,27 & 5 & 0,977 & 1 & 5 \\
\hline $\begin{array}{l}\text { Zajednički marketing i nastup na } \\
\text { stranim tržištima }\end{array}$ & 4,15 & 5 & 0,988 & 1 & 5 \\
\hline Zajedničko brendiranje & 3,85 & 5 & 1,184 & 1 & 5 \\
\hline $\begin{array}{l}\text { Poticanje zajedničkog izvoza iz } \\
\text { klastera }\end{array}$ & 3,84 & 4 & 1,080 & 1 & 5 \\
\hline $\begin{array}{l}\text { Zajednička ponuda proizvoda na } \\
\text { tržištu }\end{array}$ & 3,79 & 4 & 1,066 & 1 & 5 \\
\hline Zajednička nabava sirovina i dijelova & 3,65 & 4,5 & 1,228 & 1 & 5 \\
\hline Zajedničke prodajne aktivnosti & 3,64 & 3 & 1,112 & 1 & 5 \\
\hline Obuka menadžmenta & 3,62 & 4 & 1,155 & 1 & 5 \\
\hline $\begin{array}{l}\text { Prikupljanje podataka o tehnološkim } \\
\text { trendovima }\end{array}$ & 3,56 & 3 & 0,981 & 1 & 5 \\
\hline Primijenjena istraživanja & 3,56 & 3,4 & 0,927 & 1 & 5 \\
\hline Obuka ostalih profila kadrova & 3,42 & 3 & 1,323 & 1 & 5 \\
\hline Zajednička proizvodnja & 3,35 & 3 & 0,949 & 1 & 5 \\
\hline Temeljna istraživanja & 3,32 & 3 & 1,065 & 1 & 5 \\
\hline $\begin{array}{l}\text { Koordinacija javno-privatnih } \\
\text { investicija }\end{array}$ & 3,21 & 3 & 1,139 & 1 & 5 \\
\hline Zajedničko skladištenje & 2,76 & 3 & 1,250 & 1 & 5 \\
\hline Zajednički transport & 2,73 & 3 & 1,329 & 1 & 5 \\
\hline
\end{tabular}

Izvor: izračun autorice 
Kao što je već spomenuto u uvodnom dijelu rada, osnovna svrha postojanja HDK-a je okupljanje poslovnih subjekata registriranih u djelatnosti C16 i C31 na strukturiran i integriran način s ciljem unaprjeđenja održive konkurentnosti sektora, osobito vezano uz poticanje i promociju unutarsektorske i međusektorske suradnje. Za ostvarenje ciljeva Hrvatskog drvnog klastera neophodna je snažna suradnja kako između samih članica klastera tako i između klastera te dionika izvan klastera, poput nositelja javnih politika, ostalih poslovnih subjekata, znanstveno-istraživačkih i visoko-obrazovnih institucija. Jedan od ciljeva istraživanja je ispitati i analizirati stavove i percepcije članica vezane uz ocjenu snage i kvalitete međusobne suradnje članica klastera kao i suradnje između članica klastera i vanjskih dionika. Kada je riječ o suradnji među članovima klastera, rezultati provedenog istraživanja ukazuju na srednju jačinu suradnje (tablica 8), pri čemu se najveći dio ispitanika slaže s tvrdnjom da su putem klastera povezani s većim brojem poduzeća, različitih veličina, starosti i mogućnosti unutar industrije (50 posto ispitanika se slaže i u potpunosti slaže) te s tvrdnjom da je klaster otvoren prema primanju novih članica (48,5 posto ispitanika se slaže). Ipak, kod tih dviju tvrdnji se ne smije zanemariti i dio ispitanika koji su indiferentni (oko jedna trećina) i koji se ne slažu s ovim tvrdnjama (oko jedne petine ispitanika). Manji dio ispitanika (svega 27,3 posto) slaže se i u potpunosti s tvrdnjom da se učestalo susreću s članovima klastera u cilju razmjene ideja i resursa (27,3 posto), s tvrdnjom da njihovo poduzeće već dugo surađuje s ostalim akterima u klasteru (35,3 posto) te s tvrdnjom da je veze u klasteru teško mijenjati ( 27,3 posto).

Zanimljivo je bilo ispitati i kako članice Hrvatskog drvnog klastera ocjenjuju suradnju s dionicima izvan klastera (tablica 9). Suradnju s dionicima izvan klastera snažnom ocjenjuje 36 posto ispitanika, dok se 18,2 posto ispitanika ne slaže s tom tvrdnjom. Zanimljivo je da je čak 45,5 posto ispitanika indiferentno u odnosu na danu tvrdnju. Nadalje, najsnažnijom je ocijenjena suradnja s dobavljačima opreme, zatim dobavljačima dijelova i kupcima. Suradnja s javnim, financijskim institucijama i istraživačkim institucijama ocijenjena je slabom. Tek jedna četvrtina ispitanika smatra da Hrvatski drvni klaster ima snažnu suradnju s tim dionicima. 
I. RAŠIĆ: Suradnja i umrežavanje kao odrednice uspješnosti Hrvatskog drvnog klastera EKONOMSKI PREGLED, 72 (1) 113-154 (2021)

Tablica 8 .

OCJENA SURADNJE I UMREŽAVANJA UNUTAR KLASTERA, N = 34 .

\begin{tabular}{|l|c|c|c|}
\hline & $\begin{array}{c}\text { U potpunosti } \\
\text { se ne slažem/ } \\
\text { ne slažem se }\end{array}$ & $\begin{array}{c}\text { Niti se } \\
\text { slažem niti } \\
\text { se ne slažem }\end{array}$ & $\begin{array}{c}\text { U potpunosti } \\
\text { se slažem/ } \\
\text { slažem se }\end{array}$ \\
\hline $\begin{array}{l}\text { Ovaj klaster brzo prihvaća nove članove } \\
\text { i umrežava ih unutar klastera s drugim } \\
\text { clanovima }(\bar{x}=3,33 ; \text { Mo = 4; } \\
\text { S.D. }=1,109 ; \text { min. }=1 ; \text { maks. = 5) }\end{array}$ & $18,2 \%$ & $33,3 \%$ & $48,5 \%$ \\
\hline $\begin{array}{l}\text { Povezani smo s većim brojem poduzeća, } \\
\text { različitih veličina, starosti i mogućnosti } \\
\text { unutar industrije }(\bar{x}=3,32 ; \text { Mo = 4; S.D. } \\
=1,199 ; \text { min. }=1 ; \text { maks. = 5) }\end{array}$ & $20,6 \%$ & $29,4 \%$ & $50,0 \%$ \\
\hline $\begin{array}{l}\text { Učestalo se susrećemo s članovima } \\
\text { klastera da bismo razmijenili ideje i } \\
\text { resurse. }(\bar{x}=3,15 ; \text { Mo = 3; S.D. =0,939; } \\
\text { min. }=1 ; \text { maks. }=5)\end{array}$ & $15,2 \%$ & $57,6 \%$ & $27,3 \%$ \\
\hline $\begin{array}{l}\text { Naše poduzeće već dugo surađuje s } \\
\text { ostalim akterima u ovom klasteru. } \\
(\bar{x}=3,12 ; \text { Mo = 3; S.D. = 1,200; min. }=1 ; \\
\text { maks. }=5)\end{array}$ & $26,5 \%$ & $38,2 \%$ & $35,3 \%$ \\
\hline $\begin{array}{l}\text { Veze s akterima u ovom klasteru je teško } \\
\text { mijenjati. }(\bar{x}=3,09 ; \text { Mo = 3; } \\
\text { S.D. = 1,093; min. = 1; maks. = 5) }\end{array}$ & $24,2 \%$ & $48,5 \%$ & $27,3 \%$ \\
\hline
\end{tabular}

Izvor: izračun autorice 
Tablica 9 .

\section{OCJENA SURADNJE I UMREŽAVANJA S DIONICIMA IZVAN KLASTERA, $\mathrm{N}=34$.}

\begin{tabular}{|c|c|c|c|}
\hline & \begin{tabular}{|l|} 
Nema \\
suradnje/ \\
slaba \\
suradnja
\end{tabular} & $\begin{array}{l}\text { Suradnja } \\
\text { je } \\
\text { osrednja }\end{array}$ & $\begin{array}{l}\text { Suradnja } \\
\text { je dobra/ } \\
\text { Suradnja } \\
\text { je snažna }\end{array}$ \\
\hline $\begin{array}{l}\text { Dobavljači opreme }(\bar{x}=3,28 ; \text { Mo }=3 ; \text { S.D. }=1,198 ; \\
\text { min. }=1 ; \text { maks. }=5)\end{array}$ & $21,9 \%$ & $37,5 \%$ & $40,6 \%$ \\
\hline $\begin{array}{l}\text { Dobro smo povezani s akterima izvan klastera. } \\
(\bar{x}=3,21 ; \text { Mo }=3 ; \text { S.D. }=0,992 ; \text { min. }=1 \\
\text { maks. }=5)\end{array}$ & $18,2 \%$ & $45,5 \%$ & $36,4 \%$ \\
\hline $\begin{array}{l}\text { Dobavljači dijelova }(\mathrm{X}=3,19 ; \mathrm{Mo}=3 ; \text { S.D. }=1,23 ; \\
\min .=1 ; \text { maks. }=5)\end{array}$ & $28,1 \%$ & $34,4 \%$ & $37,5 \%$ \\
\hline $\begin{array}{l}\text { Kupci }(\bar{x}=3,31 ; \text { Mo }=3 ; \text { S.D. }=1,181 ; \text { min. }=1 \\
\text { maks. }=5)\end{array}$ & $29 \%$ & $38,7 \%$ & $32,3 \%$ \\
\hline $\begin{array}{l}\text { Visokoobrazovne institucije }(\bar{x}=3,06 ; \mathrm{Mo}=3 ; \\
\text { S.D. }=1,181 \text { min. }=1 ; \text { maks. }=5)\end{array}$ & $25,8 \%$ & $41,9 \%$ & $32,3 \%$ \\
\hline $\begin{array}{l}\text { Dobavljači usluga }(\bar{x}=2,97 ; \text { Mo }=3 ; \text { S.D. }=1,197 ; \\
\text { min. }=1 ; \text { maks. }=5)\end{array}$ & $31,3 \%$ & $37,5 \%$ & $31,3 \%$ \\
\hline $\begin{array}{l}\text { Istraživačke institucije }(\bar{x}=2,94 ; \mathrm{Mo}=3 \\
\text { S.D. }=1,19 ; \text { min. }=1 ; \text { maks. }=5)\end{array}$ & $32,3 \%$ & $41,9 \%$ & $25,8 \%$ \\
\hline $\begin{array}{l}\text { Javne institucije (središnje i lokalne države) } \\
(\bar{x}=2,81 ; \mathrm{Mo}=3 ; \text { S.D. }=1,223 ; \text { min. }=1 ; \\
\text { maks. }=5)\end{array}$ & $35,5 \%$ & $38,7 \%$ & $25,8 \%$ \\
\hline $\begin{array}{l}\text { Financijske institucije }(\bar{x}=2,27 ; \mathrm{Mo}=3 ; \\
\text { S.D. }=1,301 ; \text { min. }=1 ; \text { maks. }=5)\end{array}$ & $43,8 \%$ & $31,3 \%$ & $25,0 \%$ \\
\hline
\end{tabular}

Izvor: izračun autorice

Rezultati ovog istraživanja u suprotnosti su s nalazima literature koji ukazuju na pozitivnu vezu između klasterskog umrežavanja i poslovne uspješnosti poduzeća članica (Altenburg i Meyer-Stamer, 1999; Hervas-Oliver i Albors-Garrigos, 1997; Hendry i Brown, 2006; Chiu, 2009). Članice ne percipiraju resurse Hrvatskog drvnog klastera kao značajan izvor rasta svoje konkurentnosti (prosječne ocjene koje su dodijeljene važnosti pojedinog resursa klastera kao izvora konkurentnosti kreću se u rasponu od 2,66 do 3,18). Relativno važnijim izvorom konkurentske prednosti članice ocjenjuju činjenicu da im klaster pomaže pri pronalaženju stručnih kadrova (prosječna ocjena 2,91, modalna ocjena 4) i činjenicu da im članstvo u Hrvat- 
skom drvnom klasteru osigurava lakši pristup sajmovima i izložbama (prosječna ocjena 3,18 i modalna 3) kao i znanstveno-istraživačkim i visokoobrazovnim institucijama (prosječna ocjena 3,1 i modalna 3). S obzirom na prosjek dodijeljenih ocjena ne može se zaključiti da su oni značajan izvor rasta konkurentnosti, ali se može ustvrditi da Hrvatski drvni klaster ima značajan neiskorišteni potencijal za uspostavu i jačanje suradnje između drvne industrije i znanosti, a upravo ta vrsta suradnje čini jedan od najvažnijih elemenata inovacijskog sustava i značajnoj mjeri doprinosi rastu inovacija, poslovnom uspjehu i gospodarski rastu (Fontana, Geuna and Matt, 2006; Muscio, 2010; Ankrah i Al-Tabbaa, 2015).

\section{Tablica 10.}

OCJENA VAŽNOSTI RESURSA KLASTERA KAO IZVORA KONKURENTSKE PREDNOSTI ZA ČLANICE KLASTERA, N = 34 .

\begin{tabular}{|l|c|c|c|c|c|}
\hline & $\begin{array}{c}\text { Aritmetička } \\
\text { sredina }\end{array}$ & Mod & S.D. & $\begin{array}{c}\text { Mini- } \\
\text { mum }\end{array}$ & $\begin{array}{c}\text { Maksi- } \\
\text { mum }\end{array}$ \\
\hline Izlaganje na sajmovima i izložbama & 3,18 & 3 & 1,402 & 1 & 5 \\
\hline $\begin{array}{l}\text { Znanstvene, istraživačke i } \\
\text { visokoobrazovane institucije }\end{array}$ & 3,10 & 3 & 1,165 & 1 & 5 \\
\hline $\begin{array}{l}\text { Profesionalne institucije koje su } \\
\text { izravno povezane s temeljnom } \\
\text { djelatnošću poduzeća }\end{array}$ & 3,06 & 3 & 1,029 & 1 & 5 \\
\hline $\begin{array}{l}\text { Raspoloživost stručnih kadrova u } \\
\text { regiji (vašoj i okolnim županijama) }\end{array}$ & 2,91 & 3,4 & 1,304 & 1 & 5 \\
\hline Imidž regije (vaše i okolnih županija) & 2,90 & 3 & 1,165 & 1 & 5 \\
\hline $\begin{array}{l}\text { Odnosi u vertikalnoj kooperaciji u } \\
\text { vašoj i okolnim županijama }\end{array}$ & 2,88 & 3 & 1,023 & 1 & 5 \\
\hline Konzultantska poduzeća & 2,88 & 2 & 1,111 & 1 & 5 \\
\hline $\begin{array}{l}\text { Kupci u regiji (vašoj i okolnim } \\
\text { županijama) }\end{array}$ & 2,84 & 2 & 1,11 & 1 & 5 \\
\hline $\begin{array}{l}\text { Odnosi u horizontalnoj kooperaciji } \\
\text { u vašoj i okolnim županijama } \\
\text { (postojanje partnerstva s sličnim } \\
\text { poduzećima, vašim konkurentima) }\end{array}$ & 2,81 & 3 & 0,931 & 1 & 5 \\
\hline $\begin{array}{l}\text { Institucije koje promoviraju } \\
\text { upravljanje klasterima (npr. Agencija } \\
\text { za investicije i konkurentnost) }\end{array}$ & 2,79 & 3 & 0,927 & 1 & 5 \\
\hline Pristup kreditima & 2,75 & 4 & 1,27 & 1 & 5 \\
\hline
\end{tabular}




\begin{tabular}{|l|c|c|c|c|c|}
\hline & $\begin{array}{c}\text { Aritmetička } \\
\text { sredina }\end{array}$ & Mod & S.D. & $\begin{array}{c}\text { Mini- } \\
\text { mum }\end{array}$ & $\begin{array}{c}\text { Maksi- } \\
\text { mum }\end{array}$ \\
\hline $\begin{array}{l}\text { Lokalna infrastruktura i logistika } \\
\text { distribucija proizvoda i pristup } \\
\text { dobavljačima) }\end{array}$ & 2,72 & 2 & 1,17 & 1 & 5 \\
\hline Pristup lokalnim uslugama & 2,69 & 2 & 1,091 & 1 & 5 \\
\hline $\begin{array}{l}\text { Konkurencija u regiji (vašoj i } \\
\text { okolnim županijama) }\end{array}$ & 2,66 & 3 & 1,096 & 1 & 5 \\
\hline
\end{tabular}

Napomena: ocjene se kreću od 1 (uopće nisu izvor konkurentnosti) do 5 (u potpunosti su izvor konkurentnosti)

Izvor: izračun autorice

Nadalje, jedan od ciljeva ovog istraživanja bio je i ispitati učinak članstva u poslovnom klasteru na poslovnu uspješnost poduzeća članica (tablica 11). Među ispitanim poduzećima prevladava stav da članstvo u klasteru nema značajnijeg pozitivnog učinka na uspješnost poslovanja poduzeća. Pritom su višim ocjenama ocijenjeni učinci povezani sa suradnjom i umrežavanjem, kao primjerice da klaster pridonosi povećanoj suradnji s dobavljačima i inputa. Zanimljiv je podatak da 37,5 posto ispitanih smatra da klaster nije ispunio njihova očekivanja te da se svodi na mnogo razgovora i malo djelovanja. Također, više od polovice ispitanih, 51 posto, smatra da klaster nije doveo do snažnijeg povezivanja s obrazovnim i istraživačkim institucijama, što se može i povezati s prethodnim pitanjem u kojem članice pristup znanstvenim i visokoobrazovnim institucijama koji im osigurava klaster najčešce ocjenjuju ocjenom 3 (niti nije niti je izvor rasta konkurentnosti), a slabom i osrednjom su ocijenili i suradnju s istraživačkim institucijama (tablica 10). Većina ispitanika smatra da klaster nije pridonio rastu zaposlenosti, rastu stranih ulaganja, jačanju međunarodne konkurentnosti njihovih poduzeća i sl. 
I. RAŠIĆ: Suradnja i umrežavanje kao odrednice uspješnosti Hrvatskog drvnog klastera EKONOMSKI PREGLED, 72 (1) 113-154 (2021)

Tablica 11.

\section{UČINAK ČLANSTVA U POSLOVNOM KLASTERU NA POSLOVNU USPJEŠNOST PODUZEĆA ČLANICA, $\mathrm{N}=34$.}

\begin{tabular}{|c|c|c|c|}
\hline & $\begin{array}{l}\text { U potpunosti } \\
\text { se ne slažem/ } \\
\text { ne slažem se }\end{array}$ & \begin{tabular}{|c|} 
Niti se \\
slažem niti \\
se ne slažem \\
\end{tabular} & $\begin{array}{l}\text { U potpunosti } \\
\text { se slažem/ } \\
\text { slažem se }\end{array}$ \\
\hline $\begin{array}{l}\text { Suradnja s članicama klastera pridonijela } \\
\text { je stvaranju povjerenja }(\bar{x}=2,84, \mathrm{Mo}=3, \\
\text { S.D. }=0.969, \text { min. }=1, \text { maks. }=5)\end{array}$ & $26,7 \%$ & $56,7 \%$ & $16,7 \%$ \\
\hline $\begin{array}{l}\text { Klaster je ostvario svoje ciljeve } \\
(\bar{x}=2,78, \text { Mo }=3, \text { S.D. }=1.008 \\
\text { min. }=1, \text { maks. }=5)\end{array}$ & $28,1 \%$ & $53,1 \%$ & $18,8 \%$ \\
\hline $\begin{array}{l}\text { Suradnja s članicama klastera pridonijela } \\
\text { je transferu znanja i vještina } \\
(\bar{x}=2,68, \text { Mo }=3 \text {, S.D. }=0.945, \text { min. }=1, \\
\text { maks. }=4)\end{array}$ & $32,3 \%$ & $51,6 \%$ & $16,1 \%$ \\
\hline $\begin{array}{l}\text { Klaster je pridonio povećanoj suradnji s } \\
\text { drugim poduzećima unutar klastera } \\
(\bar{x}=2,68 \mathrm{Mo}=3, \text { S.D. }=1.013, \text { min. }=1 \\
\text { maks. }=5)\end{array}$ & $35,5 \%$ & $48,4 \%$ & $16,1 \%$ \\
\hline $\begin{array}{l}\text { Klaster je pridonio povećanoj suradnji s } \\
\text { dobavljačima inputa }(\bar{x}=2,61, \text { Mo }=3, \\
\text { S.D. }=1,103 \text {, min. }=1, \text { maks. }=5)\end{array}$ & $41,9 \%$ & $32,3 \%$ & $25,8 \%$ \\
\hline $\begin{array}{l}\text { Klaster je doveo do tješnjih veza između } \\
\text { poduzeća i obrazovnih i istraživačkih } \\
\text { institucija }(\bar{x}=2,68, \text { Mo }=3 \text {, } \\
\text { S.D. }=1.013, \text { min. }=1, \text { maks. }=5)\end{array}$ & $50,0 \%$ & $31,3 \%$ & $18,8 \%$ \\
\hline $\begin{array}{l}\text { Odnos među partnerima u klasteru je } \\
\text { visoko kooperativan }(\bar{x}=2,55, \text { Mo }=3 \text {, } \\
\text { S.D. }=0.925, \text { min. }=1, \text { maks. }=5)\end{array}$ & $41,9 \%$ & $45,2 \%$ & $12,9 \%$ \\
\hline $\begin{array}{l}\text { Kao rezultat djelovanja klastera nastale } \\
\text { su nove tehnologije }(\bar{x}=2,22, \text { Mo }=3 \text {, } \\
\text { S.D. }=1.008, \text { min. }=1, \text { maks. }=4)\end{array}$ & $56,3 \%$ & $34,4 \%$ & $9,4 \%$ \\
\hline $\begin{array}{l}\text { Klaster je pridonio povećanoj suradnji } \\
\text { s međunarodnim poduzećima unutar } \\
\text { globalnih lanaca dodane vrijednosti } \\
(\bar{x}=2,16, \text { Mo }=1, \text { S.D. }=1.081, \text { min. }=1, \\
\text { maks. }=4)\end{array}$ & $65,6 \%$ & $18,8 \%$ & $15,6 \%$ \\
\hline
\end{tabular}




\begin{tabular}{|l|c|c|c|}
\hline & $\begin{array}{c}\text { U potpunosti } \\
\text { se ne slažem/ } \\
\text { ne slažem se }\end{array}$ & $\begin{array}{c}\text { Niti se } \\
\text { slažem niti } \\
\text { se ne slažem }\end{array}$ & $\begin{array}{c}\text { U potpunosti } \\
\text { se slažem/ } \\
\text { slažem se }\end{array}$ \\
\hline $\begin{array}{l}\text { Klaster je pridonio rastu prihoda } \\
\text { poduzeća }(\bar{x}=2,13, \text { Mo }=2, \\
\text { S.D. }=0.942, \text { min. }=1, \text { maks. }=5)\end{array}$ & $71,9 \%$ & $21,9 \%$ & $6,3 \%$ \\
\hline $\begin{array}{l}\text { Klaster je povećao međunarodnu } \\
\text { konkurentnost poduzeća }(\bar{x}=2,09 \\
\text { Mo=1, S.D. }=1.118, \text { min. }=1, \text { maks. }=4)\end{array}$ & $65,6 \%$ & $18,8 \%$ & $15,6 \%$ \\
\hline $\begin{array}{l}\text { Klaster je pridonio rastu izvoza } \\
\text { proizvoda veće dodane vrijednosti } \\
(\bar{x}=2,06, \text { Mo }=1, \text { S.D. }=1.014, \text { min. }=1, \\
\text { maks. }=4)\end{array}$ & $65,6 \%$ & $25,0 \%$ & $9,4 \%$ \\
\hline $\begin{array}{l}\text { Klaster je pridonio povećanoj suradnji } \\
\text { s kupcima na međunarodnom tržištu } \\
(\bar{x}=26, \text { Mo }=1, \text { S.D. }=0.894, \text { min. }=1, \\
\text { maks. }=4)\end{array}$ & $67,7 \%$ & $29,0 \%$ & $3,2 \%$ \\
\hline $\begin{array}{l}\text { Klaster je pridonio rastu izravnih stranih } \\
\text { ulaganja (FDI) }(\bar{x}=1,91, \text { Mo }=2, \\
\text { S.D. }=0.893, \text { min. }=1, \text { maks. }=4)\end{array}$ & $78,1 \%$ & $15,6 \%$ & $6,3 \%$ \\
\hline $\begin{array}{l}\text { Klaster je pridonio rastu zaposlenosti } \\
(\bar{x}=1,91, \text { Mo }=1, \text { S.D. = 0.963, min. }=1, \\
\text { maks. =4) }\end{array}$ & $71,9 \%$ & $21,9 \%$ & $6,3 \%$ \\
\hline $\begin{array}{l}\text { Klaster je razočaranje i nema promjena } \\
(\bar{x}=2,38, \text { Mo }=1, \text { S.D. }=1.212, \text { min. }=1, \\
\text { maks. }=5)\end{array}$ & $50,0 \%$ & $31,3 \%$ & $18,8 \%$ \\
\hline $\begin{array}{l}\text { Klaster se uglavnom svodi na mnogo } \\
\text { razgovora, a malo djelovanja } \\
(\bar{x}=3,0, \text { Mo = 3, S.D. }=1,295, \text { min. }=1, \\
\text { maks. }=5)\end{array}$ & $31,3 \%$ & $31,3 \%$ & $37,5 \%$ \\
\hline
\end{tabular}

Izvor: izračun autorice 
I. RAŠIĆ: Suradnja i umrežavanje kao odrednice uspješnosti Hrvatskog drvnog klastera EKONOMSKI PREGLED, 72 (1) 113-154 (2021)

Tablica 12.

\section{UČINAK ČLANSTVA U HDK NA NAČIN POSLOVANJA PODUZEĆA ČLANICA, $\mathrm{N}=34$}

\begin{tabular}{|c|c|c|c|}
\hline & $\begin{array}{c}\text { U potpunosti } \\
\text { se ne slažem/ } \\
\text { ne slažem se }\end{array}$ & \begin{tabular}{c|} 
Niti se \\
slažem niti \\
se ne slažem
\end{tabular} & $\begin{array}{l}\text { U potpunosti } \\
\text { se slažem/ } \\
\text { slažem se }\end{array}$ \\
\hline $\begin{array}{l}\text { Uvođenje novih metoda uvođenja } \\
\text { proizvoda i kanala prodaje }(\bar{x}=2,44, \\
\text { Mo }=3, \text { S. D. }=1,045, \text { min. }=1, \text { maks. }=5)\end{array}$ & $50 \%$ & $38 \%$ & $13 \%$ \\
\hline $\begin{array}{l}\text { Prevladavanje regulatornih barijera } \\
(\mathrm{M}=2,41, \mathrm{Mo}=3, \mathrm{~S} . \mathrm{D} .=1,043, \\
\min .=1, \text { maks. }=4)\end{array}$ & $50 \%$ & $34 \%$ & $16 \%$ \\
\hline $\begin{array}{l}\text { Dijeljenje vještina i znanja }(M=2,34, \\
\text { Mo }=3, \text { S. D. }=0,827, \text { min. }=1, \text { maks. }=4)\end{array}$ & $50 \%$ & $38 \%$ & $13 \%$ \\
\hline $\begin{array}{l}\text { Poboljšani pristup kanalima distribucije } \\
\text { i nabavi }(\mathrm{M}=2,31 \mathrm{M} \mathrm{o}=3, \mathrm{~S} . \mathrm{D} .=1,061 \text {, } \\
\min .=1, \text { maks. }=4)\end{array}$ & $50 \%$ & $38 \%$ & $13 \%$ \\
\hline $\begin{array}{l}\text { Poboljšana kvaliteta usluga i roba } \\
(\mathrm{M}=2,37, \mathrm{Mo}=3, \mathrm{~S} . \mathrm{D} .=1,066 \\
\min .=1, \text { maks. }=4)\end{array}$ & $53 \%$ & $30 \%$ & $17 \%$ \\
\hline $\begin{array}{l}\text { Zadovoljavanje tehnoloških standarda } \\
(\mathrm{M}=2,28, \text { Mo }=3, \mathrm{~S} . \mathrm{D} .=1,023, \\
\min .=1, \text { maks. }=4)\end{array}$ & $53 \%$ & $41 \%$ & $6 \%$ \\
\hline $\begin{array}{l}\text { Pristup novoj tehnologiji }(\mathrm{M}=2,28, \\
\mathrm{Mo}=3, \mathrm{~S} . \mathrm{D} .=0,991, \mathrm{~min} .=1, \text { maks. }=4)\end{array}$ & $56 \%$ & $38 \%$ & $6 \%$ \\
\hline $\begin{array}{l}\text { Skraćeno vrijeme odgovora na potrebe } \\
\text { klijenata i dobavljača }(\mathrm{M}=2,25, \mathrm{Mo}=3 \text {, } \\
\text { S. D. }=1,016, \text { min. }=1, \text { maks. }=4)\end{array}$ & $53 \%$ & $38 \%$ & $9 \%$ \\
\hline $\begin{array}{l}\text { Uvođenje novih metoda određivanja } \\
\text { cijena dobara i usluga }(\mathrm{M}=2,25, \mathrm{Mo}=3, \\
\text { S. D. }=0,916, \text { min. }=1, \text { maks. }=4)\end{array}$ & $56 \%$ & $38 \%$ & $6 \%$ \\
\hline $\begin{array}{l}\text { Pristup i širenje na nova tržišta } \\
(\mathrm{M}=2,22, \mathrm{Mo}=3, \mathrm{~S} . \mathrm{D} .=0,941, \min .=1, \\
\text { maks. }=4)\end{array}$ & $63 \%$ & $28 \%$ & $9 \%$ \\
\hline $\begin{array}{l}\text { Razvoj novih proizvoda i usluga } \\
(\mathrm{M}=2,16, \mathrm{Mo}=2, \mathrm{~S} . \mathrm{D} .=0,847, \mathrm{~min} .=1, \\
\text { maks. }=4)\end{array}$ & $63 \%$ & $34 \%$ & $3 \%$ \\
\hline $\begin{array}{l}\text { Dijeljenje troškova i grupiranje resursa } \\
(\mathrm{M}=2,09, \mathrm{Mo}=1, \mathrm{~S} . \mathrm{D} .=0 \mathrm{~min} .=1 \\
\text { maks. }=4)\end{array}$ & $63 \%$ & $28 \%$ & $9 \%$ \\
\hline
\end{tabular}




\begin{tabular}{|l|c|c|c|}
\hline & $\begin{array}{c}\text { U potpunosti } \\
\text { se ne slažem/ } \\
\text { ne slažem se }\end{array}$ & $\begin{array}{r}\text { Niti se } \\
\text { slažem niti } \\
\text { se ne slažem }\end{array}$ & $\begin{array}{c}\text { U potpunosti } \\
\text { se slažem/ } \\
\text { slažem se }\end{array}$ \\
\hline $\begin{array}{l}\text { Smanjenje diverzificikacije rizika } \\
(\mathrm{M}=2,09, \text { Mo }=1, \text { S. D. }=0,803, \text { min. }=1, \\
\text { maks. }=3)\end{array}$ & $69 \%$ & $31 \%$ & \\
\hline $\begin{array}{l}\text { Ubrzano restrukturiranje }(\mathrm{M}=1,97, \\
\text { Mo = } 1, \text { S. } \text { D. }=0,999, \text { min. }=1, \text { maks. }=4)\end{array}$ & $66 \%$ & $28 \%$ & $6 \%$ \\
\hline
\end{tabular}

Izvor: izračun autorice

Vezano uz ocjenu poslovnog i gospodarskog okruženja, ispitanici vide slabosti u gotovo svim aspektima poslovnog okruženja u Hrvatskoj, prosječne ocjene kreću se od 2,03 do 2,94. Tako se čak 67,0 posto ispitanika ne slaže s tvrdnjom da je politika Vlade Republike Hrvatske stabilna i predvidljiva, 61,3 posto smatra da fokus ekonomske politike Hrvatske nije na industrijskom razvoju. Kada je riječ o javnim klasterskim politikama, dvije trećine ispitanih smatra da strategija razvoja klastera u Hrvatskoj 2011. - 2020. nije ostvarila svoje ciljeve te da nije pridonijela rastu konkurentnosti hrvatskog gospodarstva. Kao glavna ograničenja radu klastera ispitanici ocjenjuju nedostatak međusobnog povjerenja unutar klastera, neadekvatnost mjera javnih politika i nedostatak financijskih resursa. Menadžment klastera ocijenjen je pozitivno (tablica 1, prilog).

Rezultati anketnog ispitivanja ukazuju i na preporuke nositeljima javne politike za poboljšanje rezultata poslovnih klastera (vidi tablica 2, prilog). U prosjeku ispitanici najvažnijim ocjenjuju potrebu za mjerama za poticanje razvoja novih inovativnih proizvoda, zatim za poboljšanjem zakonodavnog okvira, potrebu za provedbom mjera koje su usmjerene na poticanje primjene naprednih (KET) tehnologija u sektoru kao i na poticanje primjene modernizacije proizvodnih pogona kroz robotizaciju, automatizaciju te uklapanje inovativnih IKT (3d pisači) i sofisticiranih električkih komponenata u proizvodne procese sektora. Što se tiče postojećih politika i mjera za razvoj poslovnih klastera u Hrvatskoj, ispitanici najrelevantnijom smatraju financijsku potporu projektima poduzeća, pružanje informacija o poslovnom okruženju, ulaganje u znanje (potpora znanstvene zajednice) te mjere potpore programima edukacije i obuci kadrova (tablica 3, prilog). Manje značajnima ocjenjuju mjere vezane uz poticanje socijalne interakcije, mobilnosti kadrova, umrežavanje kao i uz privlačenje poduzeća koja su izvan klastera.

Na temelju ovog dijela analize može se zaključiti kako bi prema mišljenju njegovih članica aktivnost Hrvatskog drvnog klastera u najvećoj mjeri trebala biti usmjerena prema unaprjeđenju konkurentnosti članica i cjelokupnog sektora. Najznačajnije aktivnosti koje trenutno obavlja klaster su suradnja i razmjena iskustava s domaćim i međunarodnim partnerskim klasterima, zatim umrežavanje i promidžba 
klastera (primjerice organiziranje konferencija, sudjelovanje na sajmovima, održavanje internetske stranice, zajedničko oglašavanje u medijima, učlanjenje u vodeće asocijacije i sl.); sektorsko lobiranje u Vladi RH te priprema prijava za EU projekte. Međutim, ispitanici smatraju da bi klaster trebao koordinirati i aktivnosti vezane uz informiranje o izvoznim tržištima, zajednički marketing i nastup na stranim tržištima, zajedničko brendiranje, poticanje zajedničkog izvoza iz klastera te aktivnosti zajedničke ponude proizvoda na tržištu. Rezultati upućuju na postojanje značajnog prostora za unaprjeđenje suradnje među poduzećima članicama klastera. Unapređenje i intenziviranje suradnje između članica klastera moglo bi imati pozitivne učinke na povećanje međusobnog povjerenja između aktera unutar klastera, a što je od strane ispitanih članica identificirano kao važna barijera rada Hrvatskog drvnog klastera. Nadalje, vezano uz suradnju unutar klastera, rezultati istraživanja pokazuju kako je potrebno poraditi na aktivnostima koje su vezane uz učestaliju suradnju i učestalije sastanke između članova, a kojima je cilj razmjena ideja i resursa. Jačanje suradnje unutar klastera imalo bi i pozitivne učinke na percepciju ispitanih članica da je veze između pojedinih članica klastera teško mijenjati, a ujedno bi se osnažili kapaciteti klastera. Kada je riječ o suradnji s dionicima izvan klastera, potrebno je raditi na jačanju suradnje s nositeljima vlasti, financijskim institucijama te znanstveno-istraživačkim i visokoobrazovnim institucijama. Resursi koje nudi klaster uglavnom nisu percipirani kao značajan izvor konkurentske prednosti poduzeća članica. Klaster ima značajan neiskorišten potencijal u uspostavi i jačanju suradnje drvne industrije sa znanstvenim, istraživačkim i visokoobrazovnim institucijama. Članstvo u klasteru nema utjecaja na poslovne rezultate analiziranih poduzeća, osobito na zaposlenost, ulaganja, konkurentnost i porast prihoda. Ispitanici vide slabosti u svim aspektima polovnog i gospodarskog okruženja, a najmanje su pozitivni prema gospodarskoj politici Vlade RH i općenito industrijskoj politici. Među ispitanicima također prevladava mišljenje da su temeljna ograničenja radu klastera nedostatak međusobnog povjerenja, neadekvatne ili nedostatne mjere javnih politika, nedostatni financijski resursi i kapaciteti. Najvažnije mjere javnih politika za unapređenje rada poslovnih klastera u Hrvatskoj su prema mišljenju najvećeg dijela ispitanika: poticanje razvoja novih inovativnih proizvoda, unapređenje regulatornih politika i zakonodavnog okvira, primjena naprednih tehnologija i lobiranje pri Vladi RH za razvoj infrastrukture i povezanih institucija.

U narednom dijelu analize ispituju se ključni čimbenici koji mogu utjecati na povećanje pozitivne percepcije poduzeća članica Hrvatskog drvnog klastera o uspješnosti njegovog rada. Analiza je provedena u dva koraka. U prvom koraku analize identificirane su ključne dimenzije klasterskog umrežavanja i suradnje te ključne dimenzije poslovne uspješnosti poduzeća članica klastera i uspjeha samog klastera. U drugom je koraku ispitana veza između identificiranih dimenzija suradnje i umrežavanja te percepcije članica o uspješnosti rada klastera. Korištene su analiza glavnih komponenata i višestruka regresijska analiza. 


\subsection{Rezultati faktorske analize}

Kako bi se identificirale ključne dimenzije klasterske suradnje, umrežavanja i resursa Hrvatskog drvnog klastera, provedena je faktorska analiza (analiza glavnih komponenata). Analiza je provedena na ukupno 20 varijabli koje mjere suradnju unutar klastera (pet varijabli), suradnju klastera s vanjskim dionicima (šest varijabli) te važnost klasterskih resursa kao izvora konkurentske prednosti poduzeća članica klastera (devet varijabli) (tablica 4, Prilog). Kako bi se provjerila prikladnost podataka za primjenu faktorske analize podataka, primijenjena je Kaiser-Meyer-Olkinova mjera i Bartlett test za sve varijable zajedno. KaiserMeyer-Olkinova mjera primjerenosti korelacijske matrice ovih varijabli za faktorsku analizu od 0,82 i Bartlettov test sfericiteta koji iznosi 543,528, uz p < 0,0001 (Fulgosi, 1979., str. 275-277) ukazuju da su ulazne varijable pogodne za faktorsku analizu (tablica 13).

Tablica 13.

TESTIRANJE PRIKLADNOSTI VARIJABLI ZA PROVEDBU FAKTORSKE ANALIZE

\begin{tabular}{|l|l|r|}
\hline Kaiser-Meyer-Olkinova mjera adekvatnosti uzorka & 0,822 \\
\hline \multirow{3}{*}{ Bartlettov test sfericiteta } & Hi-kvadrat & 543,53 \\
\cline { 2 - 3 } & s.s. & 190 \\
\cline { 2 - 3 } & p-vrijednost & 0,000 \\
\hline
\end{tabular}

Izvor: izračun autorice

S obzirom na to da se rezultati faktorske analize u narednom koraku koriste kao ulazne varijable za višestruku regresiju (u obliku faktorskih bodova), provedena je i ortogonalna varimax rotacija početnog faktorskog rješenja koja osigurava nezavisnost ulaznih varijabli. Rezultati analize ukazuju na postojanje četiri dimenzije suradnje i klasterskog umrežavanja (tablica 14). Ovim faktorskim rješenjem objašnjeno je 79,6 posto zajedničke varijance što se smatra prihvatljivom razinom za društvene znanosti (Hair i sur., 1987). 
I. RAŠIĆ: Suradnja i umrežavanje kao odrednice uspješnosti Hrvatskog drvnog klastera EKONOMSKI PREGLED, 72 (1) 113-154 (2021)

Tablica 14.

\section{MATRICA FAKTORSKE STRUKTURE - OSNOVNE DIMENZIJE UMREŽAVANJA I SURADNJE}

\begin{tabular}{|l|c|c|c|c|}
\hline \multicolumn{1}{|c|}{ Varijabla } & Faktor1 & Faktor2 & Faktor3 & Faktor4 \\
\hline Suradnja 1 & 0,27 & 0,01 & 0,10 & $\mathbf{0 , 8 2}$ \\
\hline Suradnja 2 & 0,31 & 0,29 & 0,19 & $\mathbf{0 , 8 0}$ \\
\hline Suradnja 3 & $-0,12$ & 0,12 & 0,10 & $\mathbf{0 , 7 3}$ \\
\hline Suradnja 4 & $-0,05$ & 0,35 & 0,45 & 0,38 \\
\hline Suradnja 5 & 0,28 & $\mathbf{0 , 8 0}$ & 0,27 & 0,18 \\
\hline Suradnja 6 & $\mathbf{0 , 7 2}$ & 0,19 & 0,26 & 0,37 \\
\hline Suradnja 7 & $\mathbf{0 , 8 2}$ & 0,25 & 0,29 & 0,18 \\
\hline Suradnja 8 & 0,33 & $\mathbf{0 , 8 2}$ & 0,27 & 0,03 \\
\hline Suradnja 9 & 0,40 & $\mathbf{0 , 8 0}$ & 0,10 & 0,10 \\
\hline Suradnja 10 & $\mathbf{0 , 7 6}$ & 0,45 & 0,19 & 0,19 \\
\hline Suradnja 11 & $\mathbf{0 , 6 1}$ & 0,55 & 0,10 & 0,26 \\
\hline Resursi 1 & 0,33 & $\mathbf{0 , 7 4}$ & 0,19 & 0,26 \\
\hline Resursi 2 & 0,56 & $\mathbf{0 , 6 7}$ & 0,24 & 0,10 \\
\hline Resursi 3 & $\mathbf{0 , 6 0}$ & 0,50 & 0,44 & 0,04 \\
\hline Resursi 4 & 0,30 & 0,05 & $\mathbf{0 , 8 1}$ & 0,13 \\
\hline Resursi 5 & $\mathbf{0 , 6 3}$ & 0,44 & 0,45 & 0,09 \\
\hline Resursi 6 & $\mathbf{0 , 5 9}$ & 0,39 & 0,48 & $-0,02$ \\
\hline Resursi 7 & 0,33 & 0,40 & $\mathbf{0 , 7 4}$ & 0,09 \\
\hline Resursi 8 & 0,24 & 0,24 & $\mathbf{0 , 8 5}$ & 0,23 \\
\hline Resursi 9 & $\mathbf{0 , 8 4}$ & 0,33 & 0,18 & $-0,06$ \\
\hline
\end{tabular}

Izvor: izračun autorice

Prvi faktor ima visoka pozitivna faktorska opterećenja na varijablama koje mjere suradnju s vanjskim dionicima: suradnju klastera s javnim i financijskim institucijama (suradnja 6 i suradnja 7), suradnju klastera s dobavljačima usluga (suradnja 10) i s dobavljačima dijelova (suradnja 11). Nadalje visoka pozitivna faktorska opterećenja na prvom faktoru imaju i varijable kojima se mjeri značaj resursa kojima raspolaže Hrvatski drvni klaster kao izvor rasta konkurentnosti poduzeća članica. To su: varijabla pristup sajmovima i izložbama (resursi 9), zatim varijabla pristup institucijama koje promoviraju upravljanje klasterima (resursi 3) te varijabla odnosi u horizontalnoj suradnji u vašoj i okolnim županijama (koja obuhvaća partnerstva sa sličnim poduzećima iz iste djelatnosti, ali izvan klastera) 
(resursi 6). Stoga je ovaj faktor označen kao „snažna suradnja s javnim, financijskim institucijama, profesionalnim udruženjima i dobavljačima, olakšan pristup sajmovima i izložbama i postojanje horizontalnih veza“. Visoka faktorska opterećenja na drugom faktoru bilježi varijabla koja mjeri otvorenost klastera prema širenju članstva, zatim varijable koje mjere intenzitet suradnje i umreženosti klastera sa znanstveno-istraživačkim i visokoobrazovnim institucijama, te važnost pristupa profesionalnim institucijama kao izvora rasta konkurentnosti“. Ovaj se faktor naziva „otvorenost klastera i suradnja sa znanstveno-istraživačkim i visokoobrazovnim institucijama“. Treći faktor okuplja tri varijable koje se odnose na resurse klastera kao izvore konkurentske prednosti poduzeća članica, i to: olakšani pristup kreditima, kupcima i konkurentnima. Četvrti faktor objašnjava najmanji dio varijance ulaznih varijabli, a visoka opterećenja na tom faktoru bilježe varijable koje mjere suradnju unutar klastera. Četvrti faktor nazvan je „,snažna suradnja i umrežavanje unutar klastera“.

Svrha druge faktorske analize je utvrditi dimenzije uspješnosti rada klastera u smislu učinaka na poslovanje poduzeća članica i uspješnost rada klastera. Faktorska analiza provedena je na ukupno 28 varijabli (tablica 4, Prilog). KaiserMeyer-Olkinova mjera primjerenosti korelacijske matrice ovih varijabli za faktorsku analizu od 0,8032 i Bartlettov test sfericiteta koji iznosi 1.121,52 p<0,01 (Fulgosi, 1984.) ukazuju da su ulazne varijable pogodne za faktorsku.

Faktorskom analizom ekstrahirane su tri dimenzije koje objašnjavaju 63,7 posto varijance ulaznih podataka (tablica 15). Prva dimenzija ima visoko faktorsko opterećenje pozitivnog predznaka na varijablama koje mjere učinak članstva u klasteru na način poslovanja poduzeća članica tijekom posljednje tri godine. Drugi faktor ima visoka faktorska opterećenja na varijablama koje mjere doprinos članstva u klasteru poslovnim rezultatima i međunarodnoj konkurentnosti poduzeća članica. Treći faktor okuplja varijable koje vrednuju uspješnost rada klastera. Uspješnost rada klastera pritom se mjeri ocjenom stupnja ostvarenja zadanih ciljeva klastera. Varijable kojima se vrednuje uspješnost rada klastera su redom: klaster je doveo do tješnjih veza između poduzeća i obrazovnih i istraživačkih institucija (uspjehklastera1), odnos među partnerima je u klasteru je visoko kooperativan (Uspjehklastera2); klaster je doveo do povećane suradnje s drugim poduzećima unutar klastera (Uspjehklastera3), suradnja sa članicama klastera pridonijela je stvaranju povjerenja (Uspjehklastera4); klaster je ostvario svoje ciljeve (Uspjehklastera7). 
I. RAŠIĆ: Suradnja i umrežavanje kao odrednice uspješnosti Hrvatskog drvnog klastera EKONOMSKI PREGLED, 72 (1) 113-154 (2021)

Tablica 15.

MATRICA FAKTORSKE STRUKTURE - OSNOVNE DIMENZIJE USPJEHA RADA HRVATSKOG DRVNOG KLASTERA

\begin{tabular}{|l|c|c|c|}
\hline \multicolumn{1}{|c|}{ Oznaka } & Faktor5 & Faktor6 & Faktor7 \\
\hline Poslovni rezultat 1 & 0,14 & $\mathbf{0 , 9 0}$ & 0,18 \\
\hline Poslovni rezultat 2 & 0,24 & $\mathbf{0 , 9 0}$ & 0,15 \\
\hline Poslovni rezultat 3 & 0,18 & $\mathbf{0 , 8 3}$ & 0,27 \\
\hline Konkurentnost 1 & 0,09 & $\mathbf{0 , 8 9}$ & 0,16 \\
\hline Konkurentnost 2 & 0,16 & $\mathbf{0 , 8 1}$ & 0,34 \\
\hline Konkurentnost 3 & 0,37 & $\mathbf{0 , 8 2}$ & 0,24 \\
\hline Uspjeh klastera 1 & 0,09 & 0,33 & 0,75 \\
\hline Uspjeh klastera 2 & 0,37 & 0,32 & $\mathbf{0 , 7 4}$ \\
\hline Uspjeh klastera 3 & 0,37 & 0,25 & $\mathbf{0 , 8 2}$ \\
\hline Uspjeh klastera 4 & 0,35 & 0,17 & $\mathbf{0 , 8 4}$ \\
\hline Uspjeh klastera 5 & 0,23 & 0,38 & $\mathbf{0 , 6 9}$ \\
\hline Uspjeh klastera 6 & 0,61 & 0,29 & 0,44 \\
\hline Uspjeh klastera 7 & 0,23 & 0,26 & $\mathbf{0 , 8 4}$ \\
\hline (Ne)uspjeh klastera 8 & 0,02 & $-0,20$ & 0,14 \\
\hline Uspjeh klastera 9 & 0,40 & 0,02 & $-0,07$ \\
\hline Učinak članice 1 & 0,37 & 0,14 & 0,32 \\
\hline Učinak članice 2 & $\mathbf{0 , 7 3}$ & 0,28 & 0,02 \\
\hline Učinak članice 3 & $\mathbf{0 , 8 1}$ & 0,12 & 0,22 \\
\hline Učinak članice 4 & $\mathbf{0 , 6 8}$ & 0,02 & 0,44 \\
\hline Učinak članice 5 & $\mathbf{0 , 7 6}$ & 0,13 & 0,45 \\
\hline Učinak članice 6 & $\mathbf{0 , 8 2}$ & 0,19 & 0,13 \\
\hline Učinak članice 7 & $\mathbf{0 , 8 1}$ & 0,21 & 0,02 \\
\hline Učinak članice 8 & $\mathbf{0 , 8 2}$ & 0,03 & 0,36 \\
\hline Učinak članice 9 & $\mathbf{0 , 7 8}$ & 0,13 & 0,37 \\
\hline Učinak članice 10 & $\mathbf{0 , 8 6}$ & 0,06 & 0,33 \\
\hline Učinak članice 11 & $\mathbf{0 , 8 9}$ & 0,20 & 0,21 \\
\hline Učinak članice 12 & $\mathbf{0 , 8 3}$ & 0,13 & 0,25 \\
\hline Učinak članice 13 & $\mathbf{0 , 7 9}$ & 0,29 & 0,25 \\
\hline
\end{tabular}

Izvor: izračun autorice 


\subsection{Model višestruke regresije - odrednice uspješnosti rada Hrvatskog drvnog klastera}

Kako bi se ispitala povezanost između dimenzija suradnje i umrežavanja i uspješnosti rada klastera, provedena je višestruka regresija. Primijenjena je uzročna analiza koja ispituje ima li nezavisna promjenjiva varijabla, statistički značajan utjecaj na zavisnu promjenjivu i koliki je taj utjecaj. Višestruka regresija je, zapravo, sustav linearnih jednadžbi s više od jedne nezavisne varijable, koji se rješava primjenom metode najmanjih kvadrata.

$$
Y_{i}=\beta_{0}+\beta_{1} X_{i 1}+\beta_{2} X_{i 2}+\beta_{3} X_{i 3}+\beta_{4} X_{i 4}+\varepsilon_{i}, \text { for } \mathrm{i}=1,2, \ldots, \mathrm{n}
$$

Zavisna varijabla u modelu je varijabla uspješnost rada klastera, a kao nezavisne varijable korištene su varijable dobivene prvom faktorskom analizom $\mathrm{u}$ obliku faktorskih bodova (eng. factor sores): X1 - ,snažna suradnja s javnim, financijskim institucijama, profesionalnim udruženjima i dobavljačima, olakšan pristup sajmovima i izložbama i postojanje horizontalnih veza između poduzeća“, X2 - otvorenost klastera i suradnja sa znanstveno-istraživačkim i visokoobrazovnim institucijama, X3 - olakšani pristup kreditima, kupcima i konkurentnima putem klastera, X4 - snažna suradnja i umrežavanje unutar klastera. 
I. RAŠIĆ: Suradnja i umrežavanje kao odrednice uspješnosti Hrvatskog drvnog klastera EKONOMSKI PREGLED, 72 (1) 113-154 (2021)

Tablica 16.

\section{SAŽETAK REZULTATA VIŠESTRUKE REGRESIJE}

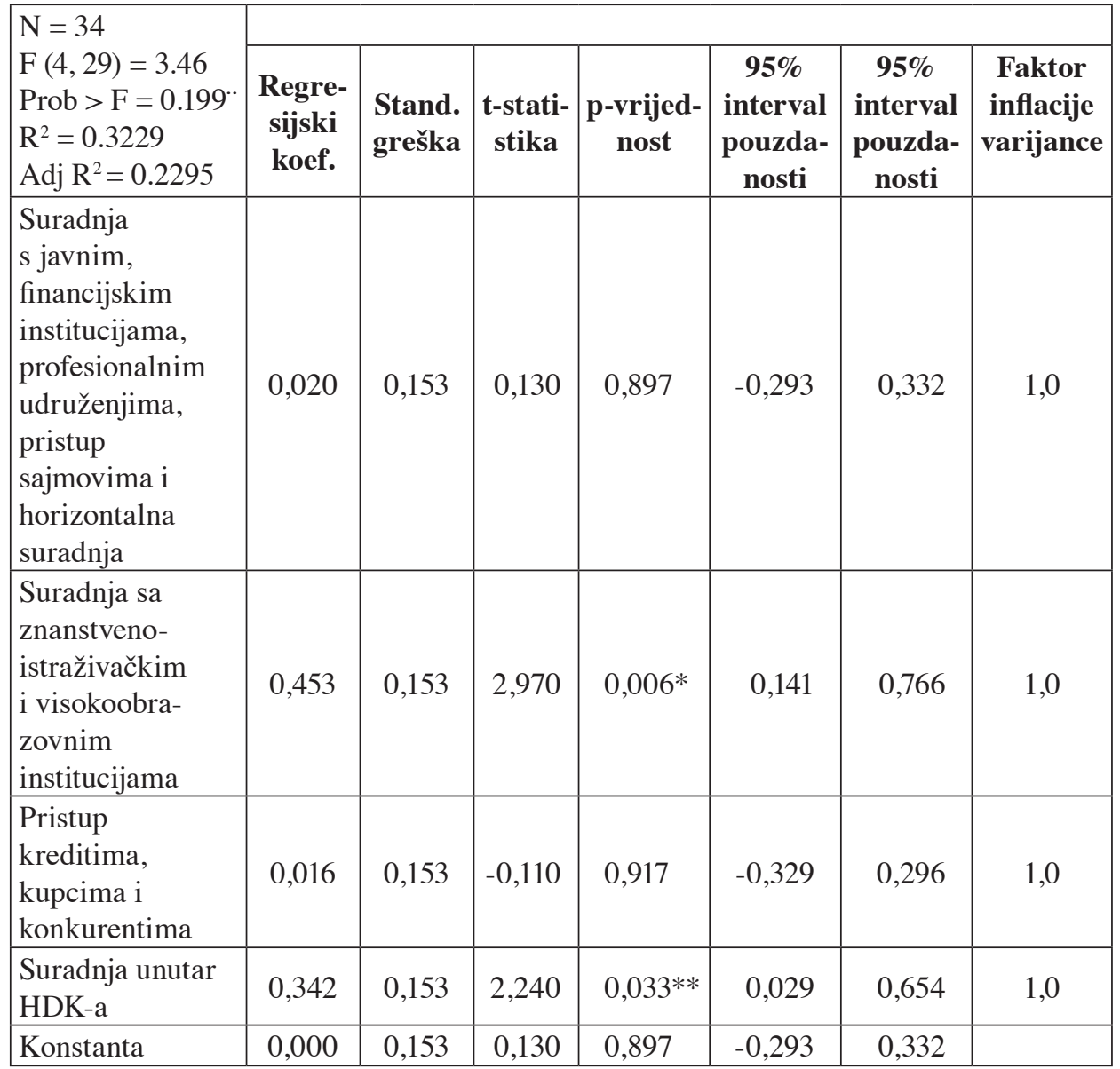

Napomena:* teorijska razina signifikantnosti od 1 posto, ** teorijska razina signifikantnosti od 5 posto

Izvor: obrada autorice

Rezultati provedene regresijske analize prikazani su u tablici 16. U zadnjem stupcu tablice dane su i vrijednosti faktora inflacije varijance koje ukazuju na nezavisnost svake pojedine varijable u odnosu na ostale članove modela. Provjera homoskedastičnosti slučajnih grešaka provedena je pomoću Breusch-Paganovog 
testa. Rezultati tog testa prikazani u tablici 17 pokazuju da ne postoji izražena heteroskedastičnost $(\mathrm{p}$-vrijednost $>$ chi2 $=0.3149$ ) slučajnih grešaka.

Tablica 17.

\section{BREUSCH-PAGAN / COOK-WEISBERG TEST POSTOJANJA HETEROSKEDSTIČNOSTI REZIDUALA}

\begin{tabular}{|l|r|}
\hline$H_{0}:$ konstantna varijanca \\
\hline Chi2 $(1)$ & 1,01 \\
\hline Prob $>$ chi2 & 0,3149 \\
\hline
\end{tabular}

Izvor: obrada autorice

Prema mišljenju ispitanika najjači pozitivan i statistički signifikantan utjecaj na njihovu percepciju uspješnosti rada Hrvatskog drvnog klastera imala je snažna suradnja sa znanstveno-istraživačkim i obrazovnim institucijama kao i otvorenost klastera prema širenju članstva. Također, rezultati provedene regresijske analize ukazuju da bi prema mišljenju članica na percepciju članica o uspjehu rada klastera pozitivno utjecala snažnija suradnja između poduzeća članica klastera odnosno umrežavanje unutar klastera. Zanimljivo je da se ovi nalazi mogu povezati s rezultatima ankete prikazanima u prvom dijelu rada koji su pokazali da ispitanici nezadovoljavajućom ocjenjuju upravo suradnju svog klastera sa znanstveno-istraživačkim sektorom i sektorom visokog obrazovanja, kao i da nedostatak međusobnog povjerenja do kojeg dolazi uslijed nedostatne suradnje između članica klastera ocjenjuju jednom od snažnijih prepreka radu klastera. Na temelju ovih rezultata može se zaključiti da bi upravo osnaživanje ovih dviju aktivnosti Hrvatskog drvnog klastera imalo značajan učinak na porast pozitivne percepcije članica klastera prema uspješnosti njegovog rada. Prema ocjenama članica postoji značajan prostor za unapređenje suradnje i umrežavanja unutar Hrvatskog drvnog klastera. S obzirom na dobivene rezultate prihvaća se prva istraživačka hipoteza da uspostavljanje i jačanje suradnje poslovnog klastera sa znanstveno-istraživačkim $i$ visokoobrazovnim institucijama ima pozitivan utjecaj i statistički signifikantan utjecaj na percepciju članica o uspješnosti rada klastera u cjelini. Također, prihvaća se $i$ hipoteza da umrežavanje i jačanje suradnje unutar poslovnog klastera ima nešto slabiji, ali još uvijek statistički signifikantan i pozitivan utjecaj na percepciju članica o uspješnosti rada klastera u cjelini.

Rezultati dobiveni ovim istraživanjem mogu biti od značajne koristi upravljačkim strukturama Hrvatskog drvnog klastera i nositeljima javnih klasterskih politika. 
I. RAŠIĆ: Suradnja i umrežavanje kao odrednice uspješnosti Hrvatskog drvnog klastera EKONOMSKI PREGLED, 72 (1) 113-154 (2021)

\section{ZAKLJUČAK}

Prikazano istraživanje prvo je empirijsko istraživanje na ovu temu provedeno u Hrvatskoj. Svrha istraživanja je ispitati koji čimbenici imaju značajan učinak na percepciju poduzeća članica poslovnog klastera o uspješnosti njegovog rada. Istraživanje je provedeno na slučaju Hrvatskog drvnog klastera. Rezultati provedene regresijske analize pokazuju kako je najznačajniji čimbenik koji može doprinijeti pozitivnijoj percepciji uspješnosti rada klastera od strane njegovih članica snažnija suradnja Hrvatskog drvnog klastera sa znanstveno-istraživačkim i visokoobrazovnim institucijama. Nadalje, kao drugi čimbenik koji ima nešto slabiji, ali još uvijek statistički signifikantan pozitivan učinak na percepciju njegovih članica prema uspješnosti rada HDK-a identificirana je snažna suradnja unutar klastera. Time su potvrđene obje istraživačke hipoteze postavljene ovim istraživanjem.

Rezultati provedene regresijske analize oslanjaju se na rezultate anketnog istraživanja prikazane putem deskriptivne statistike u prvom dijelu rada. Obje vrste suradnje ispitanici u prosjeku ocjenjuju relativno važnijim resursima koje im klaster nudi, no ujedno smatraju da su ti resursi nedovoljno iskorišteni. Stoga se može zaključiti da bi s jedne strane bez članstva u klasteru suradnja sa znanstvenoistraživačkim i visokoobrazovnim institucijama članicama bila manje dostupna, ali i da, s druge strane, HDK mogućnosti te suradnje ne iskorištava u dovoljnoj mjeri. S tim u vezi jedna od preporuka za upravljačke strukture Hrvatskog drvnog klastera bila bi da se značajan dio aktivnosti klastera usmjeri na jačanje postojećih i uspostavu novih oblika suradnje sa znanstveno-istraživačkom i akademskom zajednicom. Na važnost jačanja tog tipa suradnje ukazuju i brojna istraživanja koja upravo suradnju između znanosti i industrije ističu kao jedan od najvažnijih elemenata inovacijskog sustava koji daje snažan doprinos povećanju inovacija, poslovnom uspjehu i gospodarskom rastu (Fontana, Geuna i Matt, 2006; Muscio, 2010; Ankrah i Al-Tabbaa, 2015). Osim što postoji značajan prostor za unaprjeđenje suradnje sa sektorom znanosti i visokog obrazovanja, istraživanje pokazuje da je potrebno ojačati i suradnju unutar samog klastera, a što bi također imalo pozitivan učinak na percepciju članica o uspješnosti rada klastera. Rezultati provedene ankete prikazani u prvom dijelu rada pokazuju kako većina članica smatra da HDK treba intenzivirati aktivnosti koje se odnose na učestaliju suradnju i sastanke između članova, a kojima je cilj razmjena ideja, iskustava i resursa. Unaprjeđenje i intenziviranje suradnje između članica klastera moglo bi imati i druge pozitivne učinke poput povećanja međusobnog povjerenja unutar klastera, koje je prema rezultatima ankete ocijenjeno kao važna barijera njegovom radu. Jačanjem suradnje unutar klastera zasigurno bi se promijenila percepcija znatnog dijela članstva da je veze između pojedinih članica klastera teško mijenjati te bi se osnažili kapaciteti klastera. Stoga bi još jedna preporuka za upravljačke strukture Hrvatskog drvnog 
klastera bila da se pored jačanja suradnje sa znanosti i visokim obrazovanjem, značajni dio aktivnosti usmjeri i na jačanje suradnje unutar klastera, primjerice putem učestalijih sastanaka i zajedničkih aktivnosti

Kada je riječ o suradnji s vanjskim dionicima, pored znanstveno-istraživačkih i visokoobrazovnih institucija, rezultati ankete ukazuju i na važnost jačanja suradnje s nositeljima javne vlasti i financijskim institucijama. Većina ispitanih članica klastera smatra da bi klaster trebao koordinirati i aktivnosti vezane uz informiranje o izvoznim tržištima, zajednički marketing i nastup na stranim tržištima, zajedničko brendiranje, poticanje zajedničkog izvoza iz klastera te aktivnosti zajedničke ponude proizvoda na tržištu. Prema mišljenju članica Hrvatski drvni klaster bi trebao poraditi i na intenzivnijim aktivnostima vezanima uz lobiranje pri Vladi Republike Hrvatske (RH). Suprotno nalazima sličnih istraživanja provedenim u drugim zemljama, rezultati ovog istraživanja ukazuju da većina članica smatra kako članstvo u klasteru nema značajnijih utjecaja na njihove poslovne rezultate, osobito na zaposlenost, ulaganja, konkurentnost i porast prihoda. Razlozi kojima bi se objasnio ovaj fenomen mogli bi biti zanimljiv predmet istraživanja.

Praćenje uspješnosti rada poslovnih klastera važno je ne samo za upravljačka tijela klastera, već i za nositelje javnih klasterskih politika. U cilju formuliranja mjera klasterskih politika te ocjena učinaka provedenih mjera, nositeljima politika bi informacije o rezultatima rada klastera trebale biti od iznimne važnosti. Dodatno, identifikacija slabosti klastera bitna je kako bi se uspostavile nove mjere za poboljšanje politika razvoja klastera (DTI, 2005). Literatura koja obrađuje temu evaluacije klastera (Turok, 1990; Diez, 2001, Davis, Arturs, Cassidy i Wolfe., 2006) naglasak stavlja na evaluaciju klasterskih politika, definirajući pritom evaluaciju fazom životnog ciklusa politike.

Što se tiče ocjene poslovnog i gospodarskog okruženja, rezultati ovog istraživanja ukazuju kako članice HDK-a vide slabosti u svim aspektima svog okruženja, a najmanje su pozitivni prema gospodarskoj politici Vlade RH i općenito industrijskoj politici. Kao neke od ključnih barijera radu klastera ističu se neadekvatne ili nedostatne mjere javnih politika, nedostatni financijski resursi i financijski i ljudski kapaciteti klastera. Sukladno tome preporuke za unapređenje rada poslovnih klastera u Hrvatskoj za nositelje javnih politika bile bi unapređenje regulatornih politika i zakonodavnog okvira, formuliranje i provedba mjera usmjerenih na poticanje razvoja novih inovativnih proizvoda, poticanje primjene naprednih (KET) tehnologija u sektoru kao i na poticanje primjene modernizacije proizvodnih pogona kroz robotizaciju, automatizaciju te uklapanje inovativnih IKT (3d pisači) i sofisticiranih električkih komponenata u proizvodne procese sektora.

S obzirom na to da je ovo istraživanje provedeno na primjeru Hrvatskog drvnog klastera, njegovi rezultati mogu biti indikativni i za ostale poslovne klastere u Hrvatskoj, no važno je naglasiti da se oni nikako ne mogu se poopćiti na sve 
I. RAŠIĆ: Suradnja i umrežavanje kao odrednice uspješnosti Hrvatskog drvnog klastera EKONOMSKI PREGLED, 72 (1) 113-154 (2021)

poslovne klastere. Stoga se preporučuje provođenje sličnog istraživanja na reprezentativnom uzorku koji bi bio odabran iz populacije svih poslovnih klastera u Hrvatskoj.

\section{LITERATURA}

1. Altenburg, T., Meyer-Stamer, J. (1999). How to Promote Clusters: Policy Experiences from Latin America. World Development, Vol. 27(9), 1693-1713.

2. Ankrah, S. i Al-Tabbaa, O. (2015). "Universities-Industry Collaboration: A Systematic Review", Scandinavian Journal of Management, 31(3), 387-408.

3. Arrow, K.J. (1962). The economic implications of learning by doing. Review of Economic Studies, Vol. 29, 155-172.

4. Baptista, R., Swann, G. M. P. (1998). Do firms in clusters innovate more? Research Policy, Vol. 27, 525-540.

5. Bertolini, P., Giovannetti, E. (2006). Industrial districts and internationalization: the case of the agrifood industry in Modena, Italy. Entrepreneurship \& Regional Development, Vol. 18(4), 279-304.

6. Chiu, Y.T. (2009). How network competence and network location influence innovation performance. Journal of Business \& Industrial Marketing, Vol. 24 (1), 46-55.

7. Crouch, C., Farrell, H. (2001). Great Britain: Falling through the Holes in the Network Concept? U Crouch C., Le Galès P., Trigilia C., Voelzkow H. (Ur.), Local Production Systems in Europe: Rise or Demise? (str. 54-211). Oxford: Oxford University Press.

8. Davis, C.H., Arturs, D., Cassidy, E. and Wolfe, D. (2006). What Indicators for Cluster Policies in the 21st Century? Paper Prepared for Blue Sky II 2006.

9. Diez, M.A. (2001). The Evaluation of Regional Innovation and Cluster Policies: Towards a Participatory Approach. European Planning Studies, 9: 7, 907-923.

10. Dragičević, M. i Obadić, A. (2013). Klasteri i politike razvoja klastera. Zagreb: Ekonomski fakultet Sveučilišta u Zagrebu.

11. Fitzgerald, L., Johnston, R., Brignall, S., Silvestro, R. and Voss, C. (1991). Performance management in Service Businesses, London: CIMA.

12. Fontana, R., Geuna, A. i Matt, M. (2006). Factors affecting university-industry R\&D projects: the importance of searching, screening and signaling. Research Policy, Vol. 35, 309-323. 
13. Fujita, M., Thisse, J.F. (2002). Economics of Agglomeration: Cities, Industrial Location, and Regional Growth. Cambridge: Cambridge University Press.

14. Fulgosi, A. (1984). Faktorska analiza - 2. dopunjeno izd. Zagreb: Školska knjiga.

15. Hair, J. F., Tatham, R. L., Anderson, R. (2010). Multivariate data analysis 7th Edition. Person Prentice Hall.

16. Hendry, C., Brown, J. (2006). Dynamics of clustering and performance in the UK opto-electronics, Regional Studies 40, 707-725.

17. Hervas-Oliver, L.J., Albors-Garrigos, J. (2007). Do clusters capabilities matter; an empirical application of the resource based view in clusters. Entrepreneurship \& Regional Development, Vol 19 (2), 113-136.

18. Horvat, Đ. i Kovačević, V. (2004). Clusteri: put do konkurentnosti. Zagreb: Cera prom: M.E.P.

19. Hrvatski drvni klaster (2014). Godišnje izvješće za 2013. godinu.

20. Johnson, A. R., Wichern W. D. (1992). Applied Multivariate Statistical Analysis, 3rd Edition, New York: Prentice Hall, Upper Saddle River.

21. Kersan Škabić, I. (2014). Hrvatska drvna industrija - klasteri, konkurentnost i perspektive razvoja u okviru članstva u Europskoj Uniji. Poslovna izvrsnost: znanstveni časopis za promicanje kulture kvalitete i poslovne izvrsnosti, Vol. 8 (2), 57-76.

22. Krugman, P.R. (1991). Geography and Trade. MIT Press, Cambridge.

23. Lorenzen, M. (2005.) Why do clusters change? European Urban and Regional Studies, 12 (3): 203-208.

24. Lundvall, B.A. i Johnson, B. (1994). The learning economy. Journal of Industry Studies, Vol. 1 (2), 23-42.

25. Marshall A (1890). Principles of economics. London: Macmillan.

26. Morosini, P. (2004). Industrial Clusters, Knowledge Integration and Performance. World Development, Vol. 32 (2), 305-326.

27. Mrnjavac, Ž. i Pašalić,Ž. (2000). Lokalni sustavi malih poduzeća i gospodarski razvitak: Uvodno razmatranje. U Pašalić, Ž. i Ž. Mrnjavac (Ur.). Lokalni sustavi malih poduzeća (str. 1-12). Split: Ekonomski fakultet-Split.

28. Muscio, A. (2006). Patterns of Innovation in Industrial Districts: An Empirical Analysis. Industry \& Innovation, Vol. 13 (3), 291-312.

29. Muscio, Alessandro, (2010). "What Drives the University Use of Technology Transfer Offices? Evidence from Italy", The Journal of Technology Transfer, 35(2), pp. 181-202. 
30. OECD. (1999). Boosting Innovation: The Cluster Approach. Paris: OECD Publications Service.

31. Porter, M. (1998). Location, Clusters, and the 'New' Microeconomics of competition. Business Economics, Vol. 33 (1), 7-13.

32. Porter, M.E. (1998). Clusters and the new economics of competition. Harvard Business Review, Vol. 76 (6), 77-90.

33. Romer, P.M. (1986). Increasing returns and long-run growth. Journal of Political Economy, Vol. 94, pp. 1002-1037.

34. Samaržija, L. (2014). Optimizacija drvnih klastera primjenom koncepta menadžmenta opskrbnog lanca. Doktorska disertacija. Rijeka: Ekonomski fakultet Sveučilišta u Rijeci.

35. Simmie, J., Sennett, J. (1999). Innovative clusters: global or local linkages? National Institute Economic Review, Vol. 170, 70-81.

36. Sölvell, Ö. (2009). Clusters - Balancing Evolutionary and Constructive Forces. Stockholm: Ivory Tower Publishers.

37. Tallman, S., Jenkins, M. i Henry, N. (2004). Knowledge, clusters, and competitive advantages. Academy of Management Review, 29 (2), 258-271.

38. Turok, I. (1990). Evaluation and accountability in spatial economic policy: a review of alternative approaches, Scottish Geographical Magazine, 106(1), 4-11.

\section{COOPERATION AND NETWORKING AS DETERMINANTS OF THE PERFORMANCE OF THE CROATIAN WOOD CLUSTER}

Summary

The paper presents the results of a survey conducted among company members of the Croatian Wood Cluster in June, July and August 2017. The fundamental goal is to determine factors that have a significant impact on the perception of members concerning the performance of the Croatian Wood Cluster. Perceptions and views of company members of the Croatian Wood Cluster were surveyed relating to attainment of the cluster's goals, features of the cluster network and cooperation, as well as cooperation and an assessment of the effects of the cluster on the business results of company members. Additionally, the members were requested to assess the quality of the business environment in Croatia, limits of the cluster's work and to assess important measures of public cluster policies. This paper utilises descriptive analysis methods, factor analysis and the multiple regression method. The survey results indicate that the most significant factors contributing to a positive perception by members towards the performance of the Croatian Wood Cluster is its cooperation with the science and higher education sectors and cooperation within the cluster itself. Accordingly, the results show that both identified forms of cooperation are not adequately utilised by the Croatian Wood Cluster.

Key words: cluster, industry cluster, business cluster, cooperation and networking 


\section{Prilog:}

\section{Tablica 1 .}

OGRANIČENJA ZA RAD KLASTERA, POSTOTNE FREKVENCIJE, N = 34 .

\begin{tabular}{|l|c|c|c|c|c|}
\hline & $\mathbf{1}$ & $\mathbf{2}$ & $\mathbf{3}$ & $\mathbf{4}$ & $\mathbf{5}$ \\
\hline $\begin{array}{l}\text { Nedostatak međusobnog povjerenja } \\
\text { između aktera u klasteru }\end{array}$ & $6,3 \%$ & $18,8 \%$ & $37,5 \%$ & $31,3 \%$ & $6,3 \%$ \\
\hline $\begin{array}{l}\text { Akteri su međusobna konkurencija, } \\
\text { konflikt interesa }\end{array}$ & $6,3 \%$ & $28,1 \%$ & $46,9 \%$ & $12,5 \%$ & $6,3 \%$ \\
\hline Nedostatak financijskih resursa & $6,3 \%$ & $15,6 \%$ & $43,8 \%$ & $21,9 \%$ & $12,5 \%$ \\
\hline Loš menadžment & $9,4 \%$ & $43,8 \%$ & $28,1 \%$ & $12,5 \%$ & $6,3 \%$ \\
\hline $\begin{array}{l}\text { Aktivnosti koje klaster provodi nisu } \\
\text { relevantni }\end{array}$ & $15,6 \%$ & $21,9 \%$ & $46,9 \%$ & $12,5 \%$ & $3,1 \%$ \\
\hline Mjere na razini države nisu relevantne & $6,3 \%$ & $15,6 \%$ & $40,6 \%$ & $21,9 \%$ & $15,6 \%$ \\
\hline Nedostatak kapaciteta poslovnog klastera & $3,1 \%$ & $18,8 \%$ & $53,1 \%$ & $18,8 \%$ & $6,3 \%$ \\
\hline
\end{tabular}

Napomena: ocjene se kreću od 1 (čimbenik ne predstavlja ograničenje) do 5 (čimbenik je veliko ograničenje)

Izvor: obrada autora 
I. RAŠIĆ: Suradnja i umrežavanje kao odrednice uspješnosti Hrvatskog drvnog klastera EKONOMSKI PREGLED, 72 (1) 113-154 (2021)

Tablica 2.

\section{DESKRIPTIVNA STATISTIKA OCJENA RELEVANTNOSTI PREPORUKA NOSITELJIMA JAVNE POLITIKE ZA POBOLJŠANJE REZULTATA POSLOVNIH KLASTERA, $\mathrm{N}=34$.}

\begin{tabular}{|l|c|c|c|c|c|}
\hline & $\begin{array}{c}\text { Aritmetička } \\
\text { sredina }\end{array}$ & Mod & S. D. & $\begin{array}{c}\text { Mini- } \\
\text { mum }\end{array}$ & $\begin{array}{c}\text { Maksi- } \\
\text { mum }\end{array}$ \\
\hline $\begin{array}{l}\text { Poticanje razvoja novih inovativnih } \\
\text { proizvoda }\end{array}$ & 4,1 & 4,5 & 0,93 & 1 & 5 \\
\hline Poboljšanje zakonodavnog okvira & 4,0 & 4 & 1,05 & 1 & 5 \\
\hline $\begin{array}{l}\text { Primjena naprednih (KET) tehnologija } \\
\text { u sektoru }\end{array}$ & 3,9 & 4,5 & 1,01 & 1 & 5 \\
\hline $\begin{array}{l}\text { Lobiranje za razvoj infrastrukture i } \\
\text { potpornih institucija }\end{array}$ & 3,9 & 4 & 0,89 & 1 & 5 \\
\hline $\begin{array}{l}\text { Poticanje modernizacije proizvodnih } \\
\text { pogona kroz robotizaciju, automatiza- } \\
\text { ciju, te uklapanje inovativnih IKT (3d } \\
\text { pisači) i sofisticiranih električkih kom- } \\
\text { ponenata u proizvodne procese sektora }\end{array}$ & 3,8 & 4 & 0,98 & 1 & 5 \\
\hline $\begin{array}{l}\text { Omogućiti transfer najboljih iskustava i } \\
\text { modela razvoja iz klastera u razvijenim } \\
\text { zemljama EU-a kako bi se nadoknadio } \\
\text { manjak iskustva i poboljšala efikasnost } \\
\text { u upravljanju hrvatskim klasterima }\end{array}$ & 3,8 & 5 & 1,17 & 1 & 5 \\
\hline $\begin{array}{l}\text { Uključivanje u međunarodni lanac } \\
\text { vrijednosti }\end{array}$ & 3,8 & 4 & 0,96 & 1 & 5 \\
\hline $\begin{array}{l}\text { Poticanje povezivanja javnog, privatnog } \\
\text { i znanstveno-istraživačkog sektora } \\
\text { kroz poslovne klastere i klaster } \\
\text { konkurentnosti }\end{array}$ & 3,8 & 4 & 1,05 & 1 & 5 \\
\hline $\begin{array}{l}\text { Ubrzanje aktivnosti unutar SMART } \\
\text { strategije kako bi se dala podrška } \\
\text { razvoju novih proizvoda i usluga } \\
\text { jačajući istraživanje, razvoj i inovacije }\end{array}$ & 3,7 & 4 & 1,00 & 1 & 5 \\
\hline $\begin{array}{l}\text { Podrška razvoju edukacijskih programa } \\
\text { u okviru Centara kompetencije kojima } \\
\text { se potiče cijelo-životno obrazovanje }\end{array}$ & 3,6 & 3 & 1,04 & 1 & 5 \\
\hline $\begin{array}{l}\text { Ubrzanje programa Centara } \\
\text { kompetencija (CEKOM) }\end{array}$ & 3,5 & 4 & 0,94 & 1 & 5 \\
\hline
\end{tabular}

Napomena: ocjene se kreću od 1 (potpuno nevažna mjera) do 5 (izrazito važna mjera)

Izvor: obrada autora. 
Tablica 3 .

\section{DESKRIPTIVNA STATISTIKA OCJENA RELEVANTNOSTI MJERA JAVNIH KLASTERSKIH POLITIKA U HRVATSKOJ, $\mathrm{N}=34$.}

\begin{tabular}{|l|c|c|c|c|c|}
\hline & $\begin{array}{c}\text { Aritmetička } \\
\text { sredina }\end{array}$ & Mod & S. D. & $\begin{array}{c}\text { Mini- } \\
\text { mum }\end{array}$ & $\begin{array}{c}\text { Maksi- } \\
\text { mum }\end{array}$ \\
\hline $\begin{array}{l}\text { Financijska potpora projektima } \\
\text { poduzeća }\end{array}$ & 4,25 & 5 & 0,984 & 1 & 5 \\
\hline $\begin{array}{l}\text { Pružanje informacija o poslovnom } \\
\text { okruženju }\end{array}$ & 4,06 & 5 & 1,059 & 1 & 5 \\
\hline $\begin{array}{l}\text { Ulaganje u znanje - projekti } \\
\text { znanstvene zajednice }\end{array}$ & 4,03 & 5 & 1,015 & 1 & 5 \\
\hline Pružanje informacija o izvoznom tržištu & 4,00 & 5 & 1,146 & 1 & 5 \\
\hline $\begin{array}{l}\text { Potpora programima edukacije i obuci } \\
\text { kadrova }\end{array}$ & 4,00 & 4 & 1,031 & 1 & 5 \\
\hline Potpora istraživačkim projektima & 3,97 & 4 & 0,951 & 1 & 5 \\
\hline $\begin{array}{l}\text { Savjetovanje ili pružanje konzultacija } \\
\text { individualnim poduzećima }\end{array}$ & 3,85 & 4 & 1,093 & 1 & 5 \\
\hline Pružanje informacija o tehnologiji & 3,85 & 4 & 1,149 & 1 & 5 \\
\hline $\begin{array}{l}\text { Privlačenje poduzeća koja su izvan u } \\
\text { klaster }\end{array}$ & 3,64 & 4 & 0,929 & 1 & 5 \\
\hline Potpora izgradnji fizičke infrastrukture & 3,64 & 4 & 0,895 & 1 & 5 \\
\hline Potpora umrežavanju i kolaboraciji & 3,61 & 4 & 0,933 & 1 & 5 \\
\hline Potpora mobilnosti kadrova & 3,55 & 4 & 0,833 & 1 & 5 \\
\hline Poticanje socijalne interakcije & 3,48 & 3 & 0,906 & 1 & 5 \\
\hline
\end{tabular}

Napomena: ocjene se kreću od 1 (potpuno nevažna mjera) do 5 (izrazito važna mjera)

Izvor: obrada autorice 
I. RAŠIĆ: Suradnja i umrežavanje kao odrednice uspješnosti Hrvatskog drvnog klastera EKONOMSKI PREGLED, 72 (1) 113-154 (2021)

Tablica 4.

ULAZNE VARIJABLE ZA PRVU FAKTORSKU ANALIZU

\begin{tabular}{|l|l|}
\hline Varijabla & Opis varijable \\
\hline Suradnja1 & Poduzeće već dugo surađuje s ostalim akterima u ovom klasteru \\
\hline Suradnja2 & $\begin{array}{l}\text { Učestalo se susrećemo s našim parterima - članovima klastera } \\
\text { (npr. dobavljačima) da bi razmijenili ideje i resurse }\end{array}$ \\
\hline Suradnja3 & $\begin{array}{l}\text { Povezani smo s većim brojem poduzeća, različitih veličina, starosti i } \\
\text { mogućnosti unutar industrije }\end{array}$ \\
\hline Suradnja4 & $\begin{array}{l}\text { Povezani smo s većim brojem poduzeća, različitih veličina, starosti i } \\
\text { mogućnosti unutar industrije }\end{array}$ \\
\hline Suradnja5 & $\begin{array}{l}\text { Ovaj klaster brzo prihvaća nove članove i umreži ih unutar klastera } \\
\text { s drugim članovima }\end{array}$ \\
\hline Suradnja6 & Suradnja s javnim institucijama (središnje i lokalne države) \\
\hline Suradnja7 & Suradnja klastera s financijskim institucijama \\
\hline Suradnja8 & Suradnja klastera s visokoobrazovnim institucijama \\
\hline Suradnja9 & Suradnja klastera sa znanstveno-istraživačkim institucijama \\
\hline Suradnja10 & Suradnja klastera s dobavljačima usluga \\
\hline Suradnja11 & Suradnja klastera s dobavljačima dijelova \\
\hline Resursi1 & Razvojno, istraživačke i obrazovne institucije (npr. fakulteti, javni instituti) \\
\hline Resursi2 & $\begin{array}{l}\text { Profesionalne institucije koje su direktno povezane s temeljnom } \\
\text { djelatnošću vašeg poduzeća (npr. razna udruženja, asocijacije) }\end{array}$ \\
\hline Resursi3 & Institucije koje promoviraju upravljanje klasterima \\
\hline Resursi4 & Pristup kreditima \\
\hline Resursi5 & Imidž regije (vaše i okolnih županija) \\
\hline Resursi6 & $\begin{array}{l}\text { Odnosi u horizontalnoj kooperaciji u vašoj i okolnim županijama } \\
\text { (postojanje partnerstva s sličnim poduzećima, vašim konkurentima) }\end{array}$ \\
\hline Resursi7 & Kupci u regiji (vašoj i okolnim županijama) \\
\hline Resursi8 & Konkurencija u regiji (vašoj i okolnim županijama) \\
\hline Resursi9 & Izlaganje na sajmovima i izložbama \\
\hline
\end{tabular}

Izvor: sistematizacija autorice 
Tablica 5 .

\section{ULAZNE VARIJABLE ZA DRUGU FAKTORSKU ANALIZU}

\begin{tabular}{|c|c|}
\hline Varijabla & Opis varijable \\
\hline Poslovnirezultat1 & Klaster je pridonio rastu prihoda poduzeća \\
\hline Poslovnirezultat2 & Klaster je pridonio rastu zaposlenosti \\
\hline Poslovnirezultat3 & Klaster je pridonio rastu izvoza proizvoda veće dodane vrijednosti \\
\hline Konkunkurentnost1 & Klaster je povećao međunarodnu konkurentnost poduzeća \\
\hline Konkunkurentnost2 & $\begin{array}{l}\text { Klaster je pridonio povećanoj suradnji s međunarodnim } \\
\text { poduzećima unutar globalnih lanaca dodane vrijednosti }\end{array}$ \\
\hline Konkurentnost3 & Klaster je pridonio rastu izravnih stranih ulaganja \\
\hline Uspjehklastera1 & $\begin{array}{l}\text { Klaster je doveo do tješnjih veza između poduzeća i obrazovnih } \\
\text { i istraživačkih institucija }\end{array}$ \\
\hline Uspjehklastera2 & Odnos među partnerima je u klasteru je visoko kooperativan \\
\hline Uspjehklastera3 & $\begin{array}{l}\text { Klaster je pridonio povećanoj suradnji s drugim poduzećima } \\
\text { unutar klastera }\end{array}$ \\
\hline Uspjehklastera4 & Suradnja sa članicama klastera pridonijela je stvaranju povjerenja \\
\hline Uspjehklastera5 & $\begin{array}{l}\text { Suradnja sa članicama klastera pridonijela je transferu znanja i } \\
\text { vještina }\end{array}$ \\
\hline Uspjehklastera6 & Kao rezultat djelovanja klastera nastale su nove tehnologije \\
\hline Uspjehklastera7 & Klaster je ostvario svoje ciljeve \\
\hline (Ne)uspjehklastera8 & Klaster je razočaranje i nema promjena \\
\hline Uspjehklastera9 & Dijeljenje vještina i znanja \\
\hline Učinakčlanicel & Ubrzano restrukturiranje \\
\hline Učinakčlanice2 & Poboljšani pristup kanalima distribucije i nabavi \\
\hline Učinakčlanice3 & Pristup novoj tehnologiji \\
\hline Učinakčlanice4 & Razvoj novih proizvoda i usluga \\
\hline Učinakčlanice 5 & Dijeljenje troškova i grupiranje resursa \\
\hline Učinakčlanice6 & Smanjenje diverzificikacije rizika \\
\hline Učinakčlanice7 & Zadovoljavanje tehnoloških standarda \\
\hline Učinakčlanice8 & Prevladavanje regulatornih barijera \\
\hline Učinakčlanice9 & Poboljšana kvaliteta usluga i roba \\
\hline Učinakčlanice10 & Skraćeno vrijeme odgovora na potrebe klijenata i dobavljača \\
\hline Učinakčlanice11 & Uvođenje novih metoda predstavljanja proizvoda i kanala prodaje \\
\hline Učinakčlanice12 & Uvođenje novih metoda određivanja cijena dobara i usluga \\
\hline Učinakčlanice13 & Pristup i širenje na nova tržišta \\
\hline
\end{tabular}

Izvor: sistematizacija autorice 